\title{
The Enigma of Double-stranded RNA (dsRNA) Associated with Mushroom Virus X (MVX)
}

\author{
Juluri R. Rao1, 2*, David W. A. Nelson', and \\ Stephen McClean ${ }^{3}$
}

${ }^{1}$ Applied Plant Science Division, Agri-food and Biosciences Institute (AFBI), Northern Ireland, UK

${ }^{2}$ The Queen's University of Belfast Newforge Lane, Belfast, Northern Ireland, BT9 5PX, UK

${ }^{3}$ Centre for Molecular Biosciences, University of Ulster, Coleraine campus, Cromore Road, Coleraine BT 52 1SA, Northern Ireland, UK

\begin{abstract}
New variants of pathogenic fungal viruses are emerging and they are enigmatic in revealing their molecular identity and of their origin. Double-stranded RNAs, some in non-encapsidated forms are increasingly becoming causal agents for sporadic diseases and are consistently associated with a complex profile of dsRNAs, presumably of (multiple) viral origin present in the host while the same are conspicuously absent in healthy (looking) counterparts. The emergence of an unusual Agaricus bisporus mushroom 'patch disease' first reported in 1996, later termed as 'mushroom virus $X$ ' (MVX), exhibited a wide range of symptoms (e.g. barren patches beside healthy looking mushrooms, arrested pins, premature opening, brown, off-colour and distortions in shape). A variable compendium of novel 26 (dsRNA) elements, ranging in sizes between $20.2 \mathrm{~kb}$ to $0.64 \mathrm{~kb}$, several of them $(17 / 26)$ in non-encapsidated form have been shown to occur in the diseased mushroom fruiting bodies and are thought to comprise multiple viruses. Ten years on, this devastating disease is now more widespread and prevalent in a number of European countries (e.g. The Netherlands, Ireland) ranging from occasional to severe outbreaks leading to crop losses. Impressive data has been accumulated on the symptoms, but the potential aetiological sources, biochemical and molecular characterizations corresponding to the symptoms visà-vis MVX linked dsRNAs still remain either elusive or unclear. We have overviewed mainly the molecular findings of research groups working on MVX in these countries together with our own work on MVX in Northern Ireland. To date, the results reviewed suggest that with the exception of 4 low molecular weight dsRNA bands (sizes 2.0. $1.8,0.8$ and $0.6 \mathrm{~kb}$ ) which consistently were found synchronous to mushroom off-colour/browning symptoms in the UK and the Netherlands, other individual MVX dsRNAs or their banding patterns clearly lack credible relationship with other symptoms of the MVX disease complex. The issues in the molecular characterisation of the MVX dsRNAs include the disparate results on the molecular sequences obtained for some of these by the different research groups, the varying molecular
\end{abstract}

*For correspondence: jr.rao@afbini.gov.uk methods or approaches adopted by them for deciphering the nucleotide sequences of the novel dsRNAs that are different from previously encountered mushroom viruses. The future outlook and general consensus among mushroom researchers worldwide is for an urgent need to recruit international taskforce and re-focus on clarifying the symptom vis-à-vis dsRNAs in the enigmatic MVX disease complex. As crossing the cellular membrane is a key step to infection process, we have also attempted to draw parallels with other viruses in terms of the potential cell entry mechanisms for MVX dsRNAs. In the light of MVX disease and $A$. bisporus being a commercial crop worldwide in agri-food markets, and taking cue from its nearest Basidiomycete model mushroom, Coprinus cinereus whose genome mapping is completed, we also propose that it may be timely for the international research groups to renew efforts to prop up a network for sequencing the host $A$. bisporus mushroom genome ( $\sim 38 \mathrm{MB})$ for a better understanding of host-pathogen relationships.

\section{Introduction}

A number of new plant pathogenic and fungal viruses are emerging and some of their molecular apparatus such as single-stranded (ss) or double-stranded (ds) RNAs, viral coat proteins, the genetic organisations and/or sequences are proving very difficult to designate them in one family or the other. Molecular characterisations of new viruses including nucleotide sequence and organisation of singlestranded (ss) or double-stranded (ds) RNAs per se are essential for accurate disease diagnostics, infection management and eventually for control strategies to be drawn. For instance, the molecular characteristics of mycoviral double-stranded RNAs (dsRNAs) normally hold clues not only to their aetiology but also their own genesis. For example, in plants, two cherry diseases viz., the Amasya Cherry Disease (ACD) and Cherry Chlorotic Rusty Disease (CCRD) observed in Italy or Turkey, are two recent disorders that are likely to be of fungal aetiology, but are also concurrently associated with complex pattern of mycoviral like 10-12 dsRNAs (Coutts et al., 2004; Covelli et al., 2004). Further studies by the group (Kozlakidis et al., 2006) revealed that while the larger dsRNAs carrying deduced RNA dependent RNA Polymerase (RDRP) sequences (responsible for replication process) are homologous to others in Totoviridae group, their relationships either to and the sequences of the smaller dsRNAs and of their role in replication details are not fully decoded, rendering at present, these viruses as novel.

A number of fungi harbour dsRNAs and some of which known as hypovirulence factors, have been the subject of intense research interest. In most of mycoviruses isolated and characterised, they appear to contain segmented, dsRNA genomes (Gillings et al., 1993). However, in some cases, they include high frequency occurrence of virus- 
like particles (VLPs) or naked virus-like dsRNA in fungal vesicles such as the case with Endothia parasitica (e.g. Hansen et al., 1985, associated with hypovirulence. Other examples include dsRNA elements in Fusarium poae (Fekete et al., 1995), entomopathogenic fungi belonging to the Paeciliomyces spp. (Inglis and Inglis, 1997), white root rot fungus Rosellinia necatrix (Arakawa et al., 2002) and last but not the least, the chestnut blight fungi Cryphonectria hypovirus (e.g. Hillman et al., 1994).

In early 1960s, a new line of research 'mycovirology' in Basidiomycetes group of fungi was gathering momentum following the publication of Hollings (1962) in Nature describing virus like particles linked to diseased Agaricus bisporus mushrooms. By early 1970s, researchers realised the significance and the link between dsRNA elements in genomic viruses and infection upon fungi. In particular, prompted in part by the La France disease of mushrooms that reached epidemic proportions in North America and Europe, dsRNA analyses (e.g. Marino et al., 1976; Morris and Dodds, 1979) became an invaluable tool and a critical factor in determining the viral etiology of the diseases. Other contemporary techniques such as electron microscopy (EM) often proved versatile for revealing virus like particles in both healthy and diseased tissues (Passmore and Frost, 1974, 1979) but unlike the dsRNAs, EM failed to distinguish morphologically similar and genetically variant viruses in diseased tissues. The 1980s saw pioneering research into exploring the prevalence and diversity of dsRNA elements vis-à-vis viruses in Agaricus bisporus commercial mushrooms in Europe (e.g. Harmsen et al., 1989) and USA (e.g. Romaine and Schlagnhaufer, 1989).

In the last two decades, our understanding of the composition, genome organisation and replication of $A$. bisporus viruses, undoubtedly has been vastly advanced, but has raised further intriguing queries in the dsRNAs or viral complexes in $A$. bisporus which includes the prevalence of Hypoviridae-like dsRNA elements in healthy mushrooms and the frequent co-infection by single-stranded RNA (ssRNA) Mushroom bacilliform virus (MBV) alongside La France virus (Romaine and Goodin, 2002). Although the research reviewed herein deals in detail upon a modest selection of published data, intensive research upon MVX disease complex is being investigated by pioneers in mushroom molecular pathology (e.g. Warwickhri, UK; Horst, The Netherlands, Sylvan Research, PA, USA). We have dealt with a broad overview of molecular investigations made mainly in the UK and in the Europe on the new patch disease since 1996 and by no means complete. No doubt developments on molecular analyses of MVX may have progressed beyond the scale and the scope of our review. The purpose of this mini-review is therefore to provide a glimpse of what lies beneath the molecular dissection of MVX and the challenges ahead at the fall of 10 years since the first emergence of MVX.

\section{The first reports of a new virus (MVX) and associated symptoms in Agaricus bisporus}

A newly recognised infectious disorder on cultivated A. bisporus initially referred to as 'patch disease' was first noted in the autumn of 1996 on a British farm and in the ensuing years an increasing number of farms in the UK experienced visible symptoms such as localised patches of mushroom bed with no primordial (pins) development with accompanying crop losses and economic implications to the industry (Gaze 1999). The following years saw the most intense debate, deliberations sprinkled with exhaustive phenotypical observations upon this new disease but offered no satisfactory explanation. It is perhaps best understood by reading the serialised graphic accounts (e.g. Gaze 2000; 2001; 2002 a, b) of the disease and interested readers may contact the Mushroom Journal office (melissa.nairn@btconnect. com). Though it does little justice to the thought provoking and often stimulating summaries articulated by Richard Gaze (www.mushroomgrowers.org), in a nutshell, the mushroom farms associated with Virus X/patch disease are often observed with barren patches beside healthy looking mushrooms, arrested pins, premature opening, brown, off-colour and distortions in shape.

\section{Molecular characterisations of MVX}

\section{MVX in Great Britain (GB), UK - the trials and} tribulations of $H R I$, UK

If one were to presume that the explanations for phenotypical expressions upon the MVX patch disease was complex and makes us to digress, the molecular characterisations of mushroom virus $X$ (MVX) offered no reprieve in that regard. To start with, several novel dsRNAs were present in diseased mushroom tissues analysed at the Horticultural Research International (HRI), Wellesbourne, UK (now better known as Warwickhri, an integral part of the University of Warwick, www.warwickhri. ac.uk), where the team of scientists had embarked upon the arduous task of unravelling the molecular viral footprints of the mysterious mushroom MVX disease. Before examining the MVX disease complex itself, a glance at the recognised mushroom viruses of the old, the new or the emerging lot as the case may be, will help to perceive what one is up against insofar as the mushroom viruses are concerned. A recent example, is that of La France virus (LIV), a member whose taxonomic position itself is far from over, as 6 out of its 9 major dsRNAs bear little resemblance to the recognized families of viruses carrying two dsRNAs within Totoviridae, Partitiviridae and Hypoviridae families (van Regenmortel et al., 2000).

Associated with La France disease is a mushroom bacilliform virus (MBV), a sole member belonging to the genus Barnaviridae (Romaine, 2000) and commonly found as a double infection with LIV affected mushrooms. An RT-PCR analysis estimated $60 \%$ of the diseased mushroom isolates in North America during a 13-year period were co-infected by LIV and MBV (Romaine et al., 1995) and that both can self replicate independently. MBV is unique, in that, it carries a positive sense ssRNA genome, a common feature of plant viruses (Tavantzis et al., 1980 and 1983). Quite unlike these known mushroom viruses (LIV or MBV) that normally carry specific sets of dsRNAs, in the case of MVX regardless of capsidation, the number of dsRNAs, their range, size and distribution over the samples were different. The dsRNAs did not resemble in their electrophoretic patterns to those 
previously described in Agaricus bisporus and were substantially different from those characterised from La France disease and was later termed as 'virus X' (Gaze et al., 2000). The symptomatic (MVX) diseased mushrooms carried at least 26 characteristic dsRNA bands (Grogan et al., 2003) ranging from sizes 0.64 to $20.2 \mathrm{Kbp}$ (Figure $1, \mathrm{I}, \mathrm{II})$.

The team of researchers at Warwickhri, UK had analysed 320 mushroom samples over a period of 6 months (2000-01) comprising both healthy and diseased mushrooms. Their extraction protocols were modified from the earlier protocols (Wach et al., 1987; Romaine and Schlagnhaufer, 1993; Goodin et al., 1997) and electropheresis was performed using $0.7 \% \mathrm{w} / \mathrm{v}$ agarose in TAE buffer and higher molecular weight bands were separated using $0.4 \% \mathrm{w} / \mathrm{v}$ agarose gel. The researchers have extensively compared their results obtained from a range of sites and farms for dsRNA elements as expressed by banding patterns of MVX disease viz., the presence or absence of bands between uninfected sites versus the mushrooms raised from phase II and phase III compost respectively. They concluded that MVX disease of the commercial mushroom Agaricus bisporus harbours a diverse range of symptoms (e.g. premature opening, pin head suppression, barren areas). Some of these could occur singly or in combinations on a given site or farm, but the variations may not fully concur with the accompanying dsRNA banding patterns. In this regard, they also inferred that the variant size and numbers of the dsRNAs profiles taken together with diverse range of symptoms observed might suggest that MVX disease complex comprised more than one virus. They have identified that three dsRNAs ( ${ }^{\mathrm{MV}} 16.2,{ }^{\mathrm{MV}} \mathrm{x} 9.4$ and ${ }^{\mathrm{MVX}} 2.4$ : depicted in bold captions in Table 1) were also routinely observed in healthy mushrooms and the remaining 23 dsRNAs (see Figure 1 , II) were present exclusively in MVX infected mushroom samples; often these varied in numbers and quantitative differences (\% in paranthesis) in sites or farms examined: Four dsRNA elements ${ }^{\mathrm{MVx}} 18.3,{ }^{\mathrm{MVx}} 7.0,{ }^{\mathrm{MVx}} 4.8,{ }^{\mathrm{MVx}} 3.6$ (41$59 \%$ ); five dsRNA elements ${ }^{\mathrm{Mv} x} 14.4,{ }^{\mathrm{Mv}} 8.6,{ }^{\mathrm{MvX}} 7.8,{ }^{\mathrm{MV} \times} 2.0$, $\operatorname{MvX} 1.8(10-26 \%)$ and the remaining dsRNAs exhibited infrequent occurrence in the samples.

Of the 26 or more MVX-linked dsRNAs, four low molecular weight dsRNAs $\left({ }^{\mathrm{MVX}} 2.0,{ }^{\mathrm{MVX}} 1.8,{ }^{\mathrm{MVx}} 0.8\right.$ and ${ }^{\mathrm{MVX}} 0.6 \mathrm{~kb}$ ) are exclusively present in MVX symptomatic mushroom tissues; these bands appeared to be consistently associated with mushroom sporophore browning syndrome and they tentatively designated these bands as diagnostic MVX bands. Two DsRNA elements of sizes 1.9 and $1.8 \mathrm{kbp}$ and the presence of $50 \mathrm{~nm}$ particles have been implicated in the spontaneous browning of Flammulina velutipes (Magae and Hayashi, 1999). However, in the light of the vast majority of the 26 dsRNAs being non-encapsidated when taken together with the fact that intensive Electron microscopy analyses at our laboratories (unpublished data) as well as elsewhere

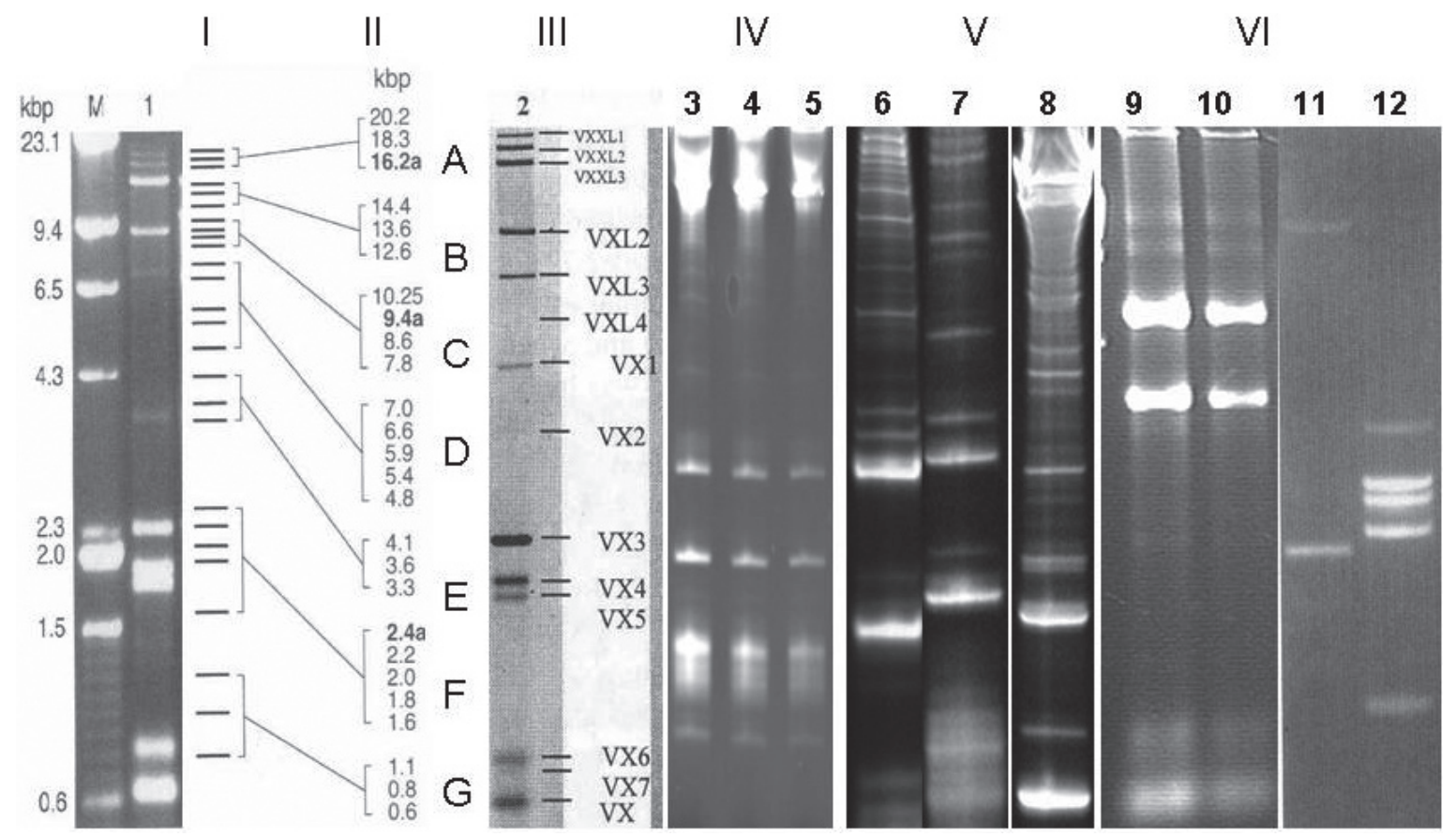

Figure 1 I. Agarose (0.7\%) electrophoresis of dsRNAs from A. bisporus (Grogan et al. 2003). M-Molecular weight (kbp) Ladder. Lanes 1-MVX infected samples from various sites/farms. Lane 11-dsRNA from asymptomatic mushrooms. Lane 12-La France virus. II. Schematic bands show the 26 dsRNAs associated with MVX. The groups A-G can vary with samples and some could occur in healthy and infected samples. III. Agarose (0.7\%) electrophoresis of dsRNAs from a typical pattern of discoloured/brown mushrooms seen in several crops in the Netherlands (Sonnenberg and Lavrijssen (2004). IV. Agarose $(0.7 \%)$ electrophoresis of MVX dsRNAs (Rao et al. 2004): Lane 3 and 4-MVX dsRNAs in the samples from a Republic of Ireland farm with MVX browning symptoms. Lane 5- samples from Northern Ireland suspected of MVX browning symptoms. V. Polyacrylamide gel electrophoresis (PAGE) of dsRNAs (Rao and Nelson, 2005; Rao et al. 2006) from MVX infected sample (browning symptoms): Lane 6 and 7- dsRNAs of MVX samples (corresponding to 3 and 4 respectively) from Republic of Ireland (Rol) farm with severe symptoms of browning. Lane 8-MVX dsRNAs from Northern Ireland sample corresponding to 5. Note the intensity of lower molecular weight bands (Lane3-8) is higher in samples from Rol than those of Northern Ireland. VI. Agarose separation of MVX dsRNA from recent (April-October 2006) samples with browning symptoms Lane 9-Rol, Lane 10-Northern Ireland. Lane 11-dsRNAs from asymptomatic (healthy looking) mushrooms beside the infected mushrooms and Lane 12-dsRNAs from La France virus (Grogan et al. 2003). 


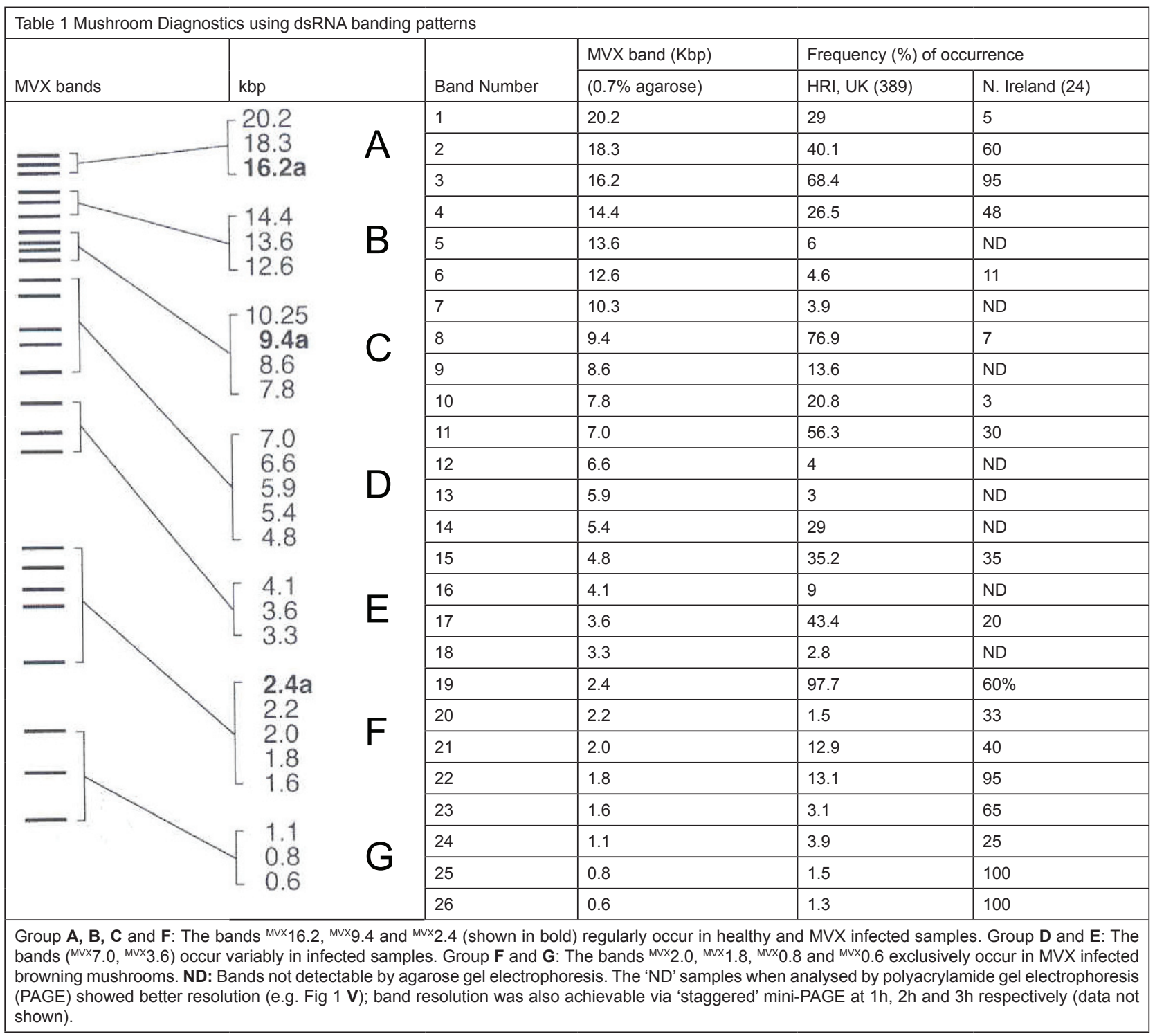

(Grogan, 2003) have failed to detect viral particles in the MVX infected mushrooms, the MVX browning symptoms in the case of Agaricus bisporus as opposed to that of Fammulina velutipes may be quite different.

As a sequel to the above observations, researchers at HRI (Adie et al., 2004) performed biometric analyses of the data comprising 389 industry samples and compiled the frequency of occurrence of MVX dsRNA elements (see also Table 1) across the mushroom farms located in Great Britain (mainland). In order to develop PCR-based diagnostic tests, they further augmented these bands in terms of group of $1-4,5-8$ and 9 or more dsRNA bands so that designing of primers and PCR tests could be streamlined to the dsRNA patterns emerging from various farm samples. Furthermore, importantly, they undertook cDNA synthesis, cloning and sequencing of specific MVX dsRNAs with a view to moving a step closer to understanding the molecular fingerprints of the putative dsRNA elements emerging from mushroom samples from infected farms. They obtained cDNAs via randompriming Superscript choice System (Life Technologies) to enable denaturation of dsRNA, purified before blunt-end ligate to EcoRV-restricted pBluescriptll KS+ and cloned into $\mathrm{E}$ coli $(\mathrm{DH} 5 \alpha)$. They attempted terminal fingerprinting of MVX dsRNAs adopted from the terminal end-labelling of specific dsRNAs using radiolabelled cytidine bis phosphate and T4 RNA ligase method described for dsRNAs of rotaviruses (Clarke and McRae, 1981) and thereby distinguish the G-position pattern generated for allowing differentiation of RNA sequences. Their findings on the sequences together with those obtained by other groups for MVX dsRNAs are summarised in Table 2.

\section{MVX in Europe - The Dutch molecular dimension}

Since 2000, in addition to Britain, mushroom farms in the Netherlands also experienced similar symptoms to that of MVX. However, in Dutch farms the symptoms were restricted to brown discoloured mushrooms and were reported to extend to some farms in Belgium and Germany linked to some of the Dutch companies. The Dutch group of scientists lead by Sonnenberg extracted dsRNAs from freeze-dried healthy or diseased mushrooms with MVX symptoms by their own methods modified described previously for La France virus (Sonnenberg et al., 1995). 


\begin{tabular}{|c|c|c|c|}
\hline DsRNA (Kbp) & $\begin{array}{l}\text { Warwickhri, UK }{ }^{1} \\
\text { Homology/similarity }\end{array}$ & $\begin{array}{l}\text { Horst, The Netherlands }{ }^{2} \\
\text { Homology/similarity }\end{array}$ & $\begin{array}{l}\text { Northern Ireland } \\
\text { Homology/similarity }\end{array}$ \\
\hline \multicolumn{4}{|l|}{18.3} \\
\hline 16.2 & & $\begin{array}{l}\text { VXXL3 (ca } 17 \text { KB) Band (VX clone } 908) \\
\text { Cryphonectria parasitica hypovirus }(\sim 2024 \\
\text { bp) }\end{array}$ & \\
\hline 14.4 & $\begin{array}{l}\text { Male Sterility dsRNA (Vicia faba) dsRNA } \\
\text { polyprotein Oryza sativa ( } 558)\end{array}$ & & $\begin{array}{l}\text { Cryphonectria parasitica } \\
\text { (partial sequence } 355 \mathrm{bp} \text { ) }\end{array}$ \\
\hline \multicolumn{4}{|l|}{13.6} \\
\hline 12.6 & & & $\begin{array}{l}\text { conserved regions of deduced RdRPs } \\
\text { (ca12 Kb) } \\
\text { Totoviridae (420bp) }\end{array}$ \\
\hline \multicolumn{4}{|l|}{10.2} \\
\hline 9.4 & $\begin{array}{l}\text { Potex virus ssRNA virus similarity with } \\
\text { Foxtail mosaic virus; clover yellow mosaic } \\
\text { virus (925) }\end{array}$ & & \\
\hline \multicolumn{4}{|l|}{8.6} \\
\hline \multicolumn{4}{|l|}{7.8} \\
\hline 7.0 & $\begin{array}{l}\text { Novel sequence- no significant similarity } \\
(559)\end{array}$ & & Novel sequence \\
\hline \multicolumn{4}{|l|}{6.6} \\
\hline \multicolumn{4}{|l|}{5.9} \\
\hline \multicolumn{4}{|l|}{5.4} \\
\hline 4.8 & & & Novel sequence \\
\hline \multicolumn{4}{|l|}{4.1} \\
\hline \multicolumn{4}{|l|}{3.3} \\
\hline 2.4 & $\begin{array}{l}\text { Novel sequence - no significant similarity } \\
(226)\end{array}$ & & \\
\hline 2.2 & $\begin{array}{l}\text { Novel sequence - no significant similarity } \\
(921)\end{array}$ & & \\
\hline 1.8 & $\begin{array}{l}\text { Novel sequence - no significant similarity; } \\
\text { low similarity to Picornaviridae (RdRP } \\
\text { motif) (657) }\end{array}$ & aNovel sequence & $\begin{array}{l}\text { Deduced RdRp sequences bacteriophage } \\
\text { PRD1 dsRNAs Cryptosporidium bayleii } \\
\text { (650bp) }\end{array}$ \\
\hline 1.6 & & ${ }^{\mathrm{b}}$ Novel sequence & \\
\hline 1.1 & & & Mushroom bacilliform virus (225bp) \\
\hline $\begin{array}{l}0.8 \\
0.6\end{array}$ & $\begin{array}{l}\text { Novel sequence Mushroom bacilliform } \\
\text { virus (one clone only) (693) } \\
\text { Novel sequence (514) }\end{array}$ & $\begin{array}{l}\text { cNovel sequence } \\
{ }^{\mathrm{d} N o v e l} \text { sequence }\end{array}$ & $\begin{array}{l}\text { ephi- } 6 \text { bacteriophage } \\
\text { fphi- } 6 \text { bacteriophage }\end{array}$ \\
\hline $\begin{array}{l}1,2 \text { For detailed } \\
\text { tions in the tex } \\
\text { dsRNA sequen }\end{array}$ & $\begin{array}{l}\text { A clone identities and hybridisation groupin } \\
\mathrm{c,d} \text { Do not hybridise with each other (VX4-VX } \\
\text {. }\end{array}$ & $\begin{array}{l}\text { adopted by Warwickhri, UK or by Horst, The } \\
\text { ) e,fHybridises with phi- } 6 \text { bacteriophage (hos }\end{array}$ & $\begin{array}{l}\text { Netherlands researchers see their publica- } \\
\text { Pseudomonas syringae) small segment }\end{array}$ \\
\hline
\end{tabular}

Sonnenberg and Lavrijssen (2004) focused their research upon the MVX bands that appeared to consistently occur in their samples exhibiting either predominantly or exclusively brown, discoloration of mushrooms (see Figure 1, III). Their attempts to clone and sequence MVX dsRNA was achieved via adaptor ligation, cDNA synthesis and cloning strategies outlined by Vreede et al. (1998) previously for developing sequence independent amplification and cloning of large dsRNA virus genome segments by poly (dA)-oligonucleotide ligation for obtaining full length copies of African horse sickness virus (AHSV) and for in vitro expression analyses.

Alternative strategies to differentiate dsRNA sequences via radio-labelled cytidine end-labelling and
T4 ligation method was to synthesise and clone fulllength cDNA segments of the large (3-4kb) dsRNA genome segments (e.g. Cashdollar et al., 1982). These evolving techniques at the time, involved polyadenylation of the genomic dsRNA and cDNA synthesis with oligo (dT) primers, followed by either blunt-ended cloning into a suitable vector or dC tailing and cloning into dG-tailed Pst1-cut pBR322 (e.g. Fukusho et al., 1989). However, such methods experienced limitations to this strategy while cloning larger segments of dsRNAs. Vreede et al. (1998) have amalgamated many of the previous methods notably that of Lambden et al. (1992) who devised steps to overcome a crucial lack of terminal sequence information while cloning the non-cultivable rotavirus via single primer 
amplification, in which, a universal primer oligonucleotide ligated to genomic dsRNA serves as a template for cDNA synthesis and amplification with a single complementary primer. Vreede et al. (1998) extended this strategy by inclusion of a $3^{\prime}$-poly A (tail) to an oligonucleotide ligated to a dsRNA genome segments as template for oligo(dT)primed cDNA synthesis (Reverse Transcription step).

Sonnenberg and Lavrijssen (2004) adopted Vreede et al. (1998) method for their cloning strategy of MVX dsRNAs and also to explore the possibility of designing a PCR-based method for the rapid diagnosis of the disease. In this way, they were able to only successfully clone MVX bands $<2.7 \mathrm{~kb}$. Their sequence analyses showed (see Table 2) that four clones represented bacterial sequences (bacterial descriptions were not published) and they concluded that these were obviously as a result of contamination. One clone (VX-908) showed significant similarity (via BLASTn search) to the Cryphonectria parasitica hypovirus (Hillman et al., 1994). A second one (VX-608), a shortened version of VX-908) and a third one (VX-708) exhibited no similarities to existing sequences. Hybridisation experiments (Sonnenberg and Lavrijssen, 2004) revealed that clones VX-708 and VX-908) hybridised only to a dsRNA VXXL3 (size 17kb), thus indicating that only parts of the largest dsRNAs were amenable for cloning and further attempts to sequence the large $17 \mathrm{~kb}$ MVX dsRNA using 5'RACE PCR afforded the researchers only a meagre $154 \mathrm{bp}$, yielding a total of $2,024 \mathrm{bp}$ deciphered sequences. Future work by this group proposes to obtain full sequences for clones representing the larger dsRNAs.

The dsRNAs VX-8 through VX-3 recovered from gels gave them enough for labelling and hybridisations carried out on total dsRNA showed that each band hybridised only to itself. This indicated that the four lower molecular weight bands of the Dutch MVX dsRNA elements (VX4 through VX-8 vis-à-vis $\mathrm{HRI}$ designated diagnostic ${ }^{M V x} 2.0,{ }^{M V x} 1.8,{ }^{M V x} 0.8$ and ${ }^{M V x} 0.6$ ) did not share sequence homology between themselves or with larger segments, indicating that each of the labelled bands represented a unique sequence and overall points out for the first time, molecular evidence (Sonnenberg and Lavrijssen, 2004) for the presence of multiple viruses. They also found that in all the discoloured (browning) Dutch mushrooms samples, the four low molecular weight diagnostic dsRNAs (VX-4 through VX-8) were always present together and of which indicated that they might represent one virus, not necessarily the causal agent of the browning symptoms, but the latter may still be a result of an unknown external stress.

\section{MVX in Ireland - the Eire brief}

Traditionally there has been a widespread interactive trade and supply of and/or exchange of raw materials for compost or casing between the islands of Ireland and Great Britain. Owing to the same, the Teagasc Research and Advisory team (Teagasc, Kinsealy Research Centre, Horticulture and Farm Forestry, Malahide Road, Dublin 17; www.teagasc.ie) in conjunction with the IMGA (Irish Mushroom Growers Association) groups had undertaken a disease audit of selected mushroom units during the early days of the onset of mushroom virus $X$ disease and of its subsequent spread in Great Britain in 2000-2001. As part of their disease surveillance and auditing process, the report (Teagasc, personal communication), on the meeting (of Teagasc on 18/12/01) regarding the offcolour/browning mushroom problem in Irish mushroom industry concluded that a survey of the Irish mushroom houses revealed no correlation (see Table 3) between the occurrence of brown mushrooms and the electrophoretic banding patterns.

The samples from Ireland were routinely sent to Warwickhri, UK who offered commercial testing services for confirmation of the presence or absence of MVX via mainly the banding patterns and other auxiliary analyses. In Ireland, a common observation was that the MVX linked off-colour/discolouration/browning were confined to first flush of mushrooms and often tended to decline or disappear in the subsequent flushes. The Irish mushroom farms adopt bag, shelf or tray systems and often in one mushroom house, the beds will be interspaced with perfectly white, healthy looking mushrooms beside a small patch of off-colour or distorted mushrooms. Their problems appear to be more related to composts and not necessarily that of a phase III or a late phase II problem and attribute the off-colour to environmental 'stress' rather than that of a viral nature. Noteworthy of the results from the personal communication, (data not shown) is the fact that compost houses having off-colour/browning mushrooms registered bands 22 and 23 (i.e. lower molecular weight MVX bands; see Figure 1) with variations of choice and usage of phase II or phase III by the commercial grower whose mushroom samples carried MVX browning symptoms; the top five or six bands (1 through 7) were all present in various combinations (Table 3 ) and did not present any correlation with either the yield or the disease symptoms; some Warwickhri designated, characteristic MvX bands were present in diseased (brown/off-colour) as well as in healthy mushrooms. Data on individual band sizes vs frequency of occurrence or system of cultivation were not available in the interim public report, perhaps due to their irrelevance to crop losses.

Recently, there have been isolated cases of MVX symptoms noted in farms in Ireland. An update (Grogan, 2006) on the transmission studies examining the changes to mushroom biology during the MVX infection via the introduction of dsRNAs to spores and mycelium both at crop and petri dish assays appeared to indicate that very low levels of infected material were capable of transmitting the dsRNA into healthy crops. Two Agaricus bisporus cultures (1283 and 1961) derived from crops bearing strong symptoms of MVX disease were able to transmit dsRNAs and cause characteristic crop delay, pinning disruption symptoms when incorporated into healthy crops at spawning stage. However, when the same were incorporated to healthy crops at a later stage, symptom expressions were more variable. To test the browning symptoms, another $A$. bisporus culture (2735) derived from a crop exhibiting strong brown discoloured mushrooms and verified to contain different MVX associated dsRNAs, also transmitted dsRNAs when incorporated into healthy crops. However, symptom expressions were either variable or absent in the early stages of the crop after introducing culture 2735 and was more consistent (persistent in 


\begin{tabular}{|c|c|c|c|c|c|c|c|}
\hline $\begin{array}{l}\text { Bands } \\
\text { (Range) }\end{array}$ & & $\begin{array}{l}\text { cy occurrence of bands } \\
\text { (33) }\end{array}$ & Compost type & System/Yield & Symptom & $\begin{array}{l}\text { Molecular Clinical } \\
\text { guide (2002) for M } \\
\text { wickhri, UK) }\end{array}$ & $\begin{array}{l}\text { Diagnostic } \\
\text { VX (War- }\end{array}$ \\
\hline None $(0)$ & 0 & 4 & Phase 2,3 & Variable & Some off-colours & \multicolumn{2}{|c|}{ 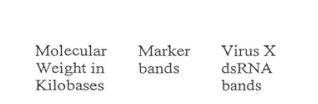 } \\
\hline Upto 2 & 3 & 8 & Phase 2, 3 & Variable & None to brown colour & \multirow{2}{*}{\multicolumn{2}{|c|}{ 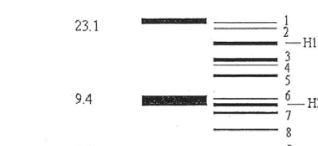 }} \\
\hline Upto 4 & 5 & 12 & Phase 2,3 & Variable & None to off colour & & \\
\hline Upto 6 & 9 & 4 & Phase 3 & Variable & No problem to some brown & \multirow{4}{*}{$4.3 \quad$} & 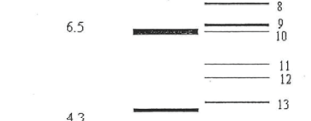 \\
\hline Upto 9 & 3 & 2 & Phase 3 & Variable & Intermittent brown & & 16 \\
\hline$>10$ & 1 & $\wedge N K$ & Phase 3 & Variable & $80 \%$ of crop off-colour & & $Z^{19}$ \\
\hline (13) & & & Phase 3 & Variable & No problem & & $\begin{array}{l}22 \\
\square\end{array}$ \\
\hline \multicolumn{8}{|c|}{$\begin{array}{l}\text { ANK-Not Known (3) } \\
\text { Samples (22 and 33) were collected from representative farms from various parts of the country. The Irish audit refers to 'total bands' versus farm oc- } \\
\text { currences and as to how these were related to either Phase 3/Phase } 2,2.5 \text { compost, the type of system (shelf/bag/block), yield and visible symptoms } \\
\text { such as off-colour or low yield. The audit observed that presence of bands 22, } 23 \text { shown in the HRI's diagnostic guide (last column) associated with } \\
\text { browning were both present in white and brown coloured mushrooms. }\end{array}$} \\
\hline
\end{tabular}

expression of browning symptoms) at later stages of crop cycles, quite the opposite of the other cultures (1283 and 1961) derived from mushrooms with a compendium of MVX disease symptoms. These results further highlight the urgent need for deducing the molecular sequences of the MVX dsRNAs, their viral origin and their relationships to host expressions.

\section{The Northern Ireland experience}

The mushroom industry Association for Northern Ireland (MIANI) closely liase with the IMGA (Irish Mushroom Growers Association) and the Mushroom growers association UK (www.mushroomgrowers.org) at various levels for trade, pest or disease management and for interlacing supply and procurement of substrate for growing mushrooms such as compost or casing materials in the British isles of Great Britain and Ireland per se.

The bulk of the mushroom industry in Northern Ireland (UK) is located in the border counties having mutually beneficial industrial liaisons with the mushroom growers of the Republic of Ireland (Eire). The mushroom industry is among the most successful rural enterprise and one of the largest horticulture markets within Northern Ireland's agri-food sector. In this respect, disease surveillance and monitoring of pathogens is of prime significance not only to the mushroom industry but also for the economic sustainability of one of the most vibrant rural entrepreneurships in the province. Given that, ignoring the prevalence of MVX problem in the neighbouring mushroom industry is an unviable option for the local mushroom growers and the industry. Samples suspected of MVX symptoms have been routinely submitted to the rural outreach research facility (Northern Ireland Horticulture and Plant Breeding Station (NIHPBS), Loughgall, Co. Armagh) based in the border region and passed on for molecular analyses at the Molecular Biology and Diagnostics Unit, Applied Plant Science Division (APSD), Agri-Food and Biosciences Institute (AFBI), a Department of Agriculture and Rural Development (DARD)'s NonDepartmental Public Body headquartered at Newforge Lane, Belfast (www.afbini.gov.uk), and sub-samples counter-verified for MVX through Warwickhri, UK.

Protocols for cDNAs synthesis, cloning and sequencing of MVX dsRNA in Northern Ireland

Prompted in part by the persistent reports in the neighbouring (Republic of Ireland) mushroom farms particularly in the border regions, that they were predominantly experiencing the browning/discolouration as the major symptom of MVX incidence, we carried out our initial work mainly towards the cloning and sequencing of the lower molecular weight MVX bands obtained from infected mushrooms. In compliance with the EU Plant Health requirements for monitoring agri-food diseases and to address our short, medium and long-term objectives, we set out twin-track approaches focused towards (a) understanding MVX dsRNA and b) developing rapid methods for detection of the MVX dsRNAs elements in the early phases of the mushroom cultivation.

\section{Isolation of nucleic acids}

The molecular characterisations of MVX dsRNAs were locally initiated and developed by the research group at Molecular Biology, Diagnostics and Environmental Health Unit (Rao et al., 2002). Fresh diseased fruiting bodies samples with MVX symptoms were finely ground 
under liquid nitrogen in a mortar. The powder was then transferred to an Eppendorf tube and the protocol described by Sonnenberg et al. (1995) was followed for isolation of dsRNAs. Isolation of total nucleic acids from spawn run compost was achieved via the procedures described by Rao et al. (2004).

We modified a T4 RNA ligase (Ambion) mediated (RLM) rapid amplification of cDNA ends of cDNA ends (RACE) protocol for dsRNA viruses (unpublished); except for variations in oligonucleotides, our protocol was broadly similar to those developed by Coutts and Livieratos (2003) useful for amplifying and sequencing difficult to purify virions directly extracted from plant and fungal tissues or unknown dsRNA templates (such as MVX) without prior sequence information. Our primers were designed from the sequences of our cDNA clones generated via the above method for either the lower molecular weight dsRNAs $\left({ }^{\mathrm{Mv}} 2.0,{ }^{\mathrm{Mvx}} 1.8,{ }^{\mathrm{Mv}} 0.8\right.$ and $\operatorname{mvx} 0.6$ ) or also of those corresponding to a selection of other MVX dsRNAs ( ${ }^{\mathrm{MVX}} 12.0, \mathrm{MVX}^{\mathrm{M}} 7.0, \mathrm{MVX}_{4} .8$ and $\left.{ }^{\mathrm{MV} X} 3.6\right)$. Our findings are depicted together with the summary of sequence analyses of other research groups (Table 2).

\section{Direct extraction of dsRNAs from mushroom composts in Northern Ireland}

In Ireland, composts have been the prime suspect and implicated in MVX problems. To this end, one of our goals was to develop rapid detection techniques capable of revealing viral dsRNAs presence in the early samples such as composts or spawn run compost in view of the fact that the method of electrophoretic pattern for determining MVX occurrence was inconsistent with compost samples. Among several current molecular techniques available, in terms of simplicity, versatility and applicability in a laboratory, the successful detection of known mushroom viruses (LIV or MBV) using RT-PCR methods (e.g. Romaine et al., 1995) and directly from composts (Sonnenberg et al., 1995) were regarded as attractive proposition and thus they served as templates for our development of rapid RT-PCR technique for viral detection. As a prequel to our eventual goal to detect MVX in composts, we initially tested the versatility of our version of RT-PCR protocol to monitor and successfully detect viruses in a separate study (Rao et al., 2003) on waste composts laden with substantive mushroom mycelial residues. Our RT-PCR tests (Rao et al., 2003) demonstrated dsRNA elements corresponding to known viruses (e.g. MBV) and others together with a range of pathogens (Watabe et al., 2004) were detected in spent mushroom composts in Ireland. We extracted total RNA directly from phase II or III composts and spent composts. We introduced an alternative step for reducing the loss of RNA from natural abrasives, degradation and prevented the interference from humic acids and other detrimental compost constituents to enzymatic reactions of (RT)PCR procedures by replacing the Biorad chelex-100 (e.g. Revill and Wright, 1997), with a low cost commercial skimmed milk powder (ca 0.1\%) previously described by Volossiouk et al. (1995) and a simple agent that protected nucleic acids in extracted compost. Our results on detection of $M V X$ in compost are presented in Figure 2 (A 1, A2; B1 and B2). Notable features include the detection of low level of mushroom bacilliform virus (MBV); putative PCR products resulting from the use of primers made from sequences corresponding to clones from low molecular weight ${ }^{\mathrm{mv}} \mathrm{dsRNAs}$ and from the bacteriophage phi-6; detection of potential presence of viral dsRNAs in cereal seeds used for spawn and in steamed spent mushroom compost. One of the control measures recommended (Gaze, 2001) is to 'cook' out the mycelia fragments left at the end of the mushroom crop prior to their disposal. Many indicator pathogens for achieving compost sanitation remain enshrined and reliant upon mainly bacterial and occasionally fungal species mortality, survival or persistence data. Despite the rapid advancement of molecular techniques (Rao et al., 2006) for pathogen detection in plant, animal or human and environmental samples, viruses have been the least studied of all pathogens and much less understood for their survival, persistence and regeneration in compost or their wastes (Jones and Martin, 2003). We do not know the host range, their survival and as to how host organisms would support or maintain viral dsRNA in harsh environments such as treated spent composts. Niche/host generalist (e g. gram negative bacteria such as E. coli, Pseudomonas spp. etc) and specialist (viral or bacteriophage) interactions are known (Wilson and Yoshimura, 1994) but viral ecology and maintenance of novel host use has been by far less investigated and scarcely understood.

Following the successful application of RT-PCR methods for viral detection in composts, we extended its application to monitor the prevalence or incidence (if any) of MVX in Northern Ireland mushroom units. A local consortium comprising scientists and advisory bodies in liaison with mushroom growers prompted a preliminary study set out to monitor the prevalence of MVX in mushroom industry within Northern Ireland in 2002-03. A total of 96 samples comprising spawn, compost, spawn run compost and mushroom fruiting bodies (first or second flush) were examined at our laboratory in Belfast by the methods described elsewhere and the final 24 of whole mushroom samples were counter verified at Warwickhri, UK, for the presence of virus $X$. The synthesis of results from the two laboratories indicated that overwhelming majority of the samples in Northern Ireland were free of many of the characteristic MVX dsRNAs (Anon., 2004; www.dardni.gov.uk/pr2004/pr041933), but exhibited feint presence of lower molecular weight bands with no outward symptoms associated with browning. To date, except occasional samples, there has been no widespread occurrence of MVX in Northern Ireland in comparison to either Britain or across the borders in the Republic of Ireland and elsewhere in Europe.

\section{Classical studies on MVX infected mushrooms with browning symptoms in Northern Ireland}

The origin of these unusual low molecular weight dsRNAs linked to the browning related symptoms in the patch disease is yet not fully known and is under intense investigation in laboratories in UK, Europe and in the USA. The 'mushroom browning' or 'bacterial brown blotch' strictly is associated with Pseudomonas syringae pv. tolasii. An extracellular toxin (tolaasin, a 
low molecular weight lipodepsipeptide) produced by this bacterium induces the browning/discoloration symptoms in mushrooms (e.g. Brodey et al., 1991; Rainey et al., 1993). In view of the fact that there has been no reports of a bacterial component insofar as browning of mushrooms associated with MVX are concerned, we set out to closely examine the skin of the MVX mushrooms for bacterial components either to rule in or rule out the possibility of bacterial involvement in the browning associated with MVX disease. The regular supply of MVX samples needed for our assays in the Northern Ireland was scarce. Thus fresh samples were obtained as and when required from consenting MVX infected farms in Eire and were recruited for our molecular method developments from time to time. Brown discoloured mushrooms (Figure 3) of Agaricus bisporus testing positive for mushroom virus $X$ related characteristic dsRNAs were collected from Irish mushroom farms. Fresh tissue scrapping was plated out onto LB agar and incubated for extended periods (sometimes up to 10 days) at $30^{\circ} \mathrm{C}$ (Figure 3) and we discovered that when our LB plates were, by chance prepared soft and incubated longer (rather than by design), the (soft) LB plates yielded bacterial colonies and plaques (Figure 3 ); the latter appearing on colony lawns consistently relied on sample freshness among other critical prerequisites.

\section{Bacterial identification in the MVX-infected mushroom skin}

Selected bacterial colonies isolated from the MVX infected mushroom skin were extracted for their total DNA using a FastDNA Spin Kit for bacteria (Bio101, Vista, California). Using PCR methods (Lane, 1991; Moore et al., 1996) and primers designed from 16S/23S rRNA sequencing, we detected Pseudomonas spp. in the skin/peel of MVX infected mushrooms. However, by employing highly specific primers, sensitive to amplify and detect tolaasin sequences, (Lee et al., 2002), we identified a number of pathovars of Pseudomonas syringae comprising pv. phaseolicola, pv. putida, and pv. tolaasii; a number of other Pseudomonas spp. also reported in our PCR based assays of the individual colonies and notable others include pv. savastonoi and pv. syringae. Pseudomonas syringae pv. tolasii (GenBank accession EF061056EF061510) was thus present in mushroom skin tissues symptomatic of MVX disease. Using multiplex nested PCR we detected Ps syr pv. putida or pv. phaseolicola
A

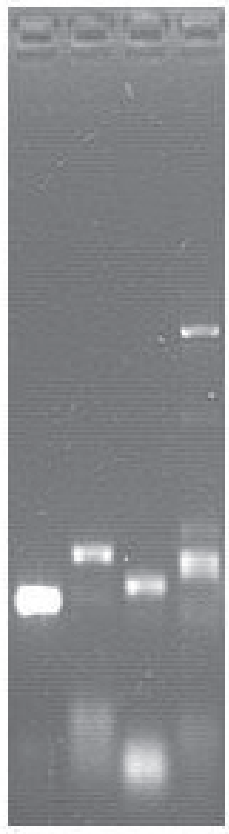

Al $1 \quad 2 \quad 3 \quad 4$

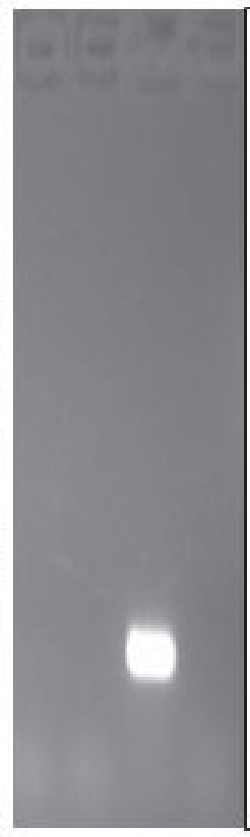

$\begin{array}{llll}5 & 6 & 7 & 8\end{array}$

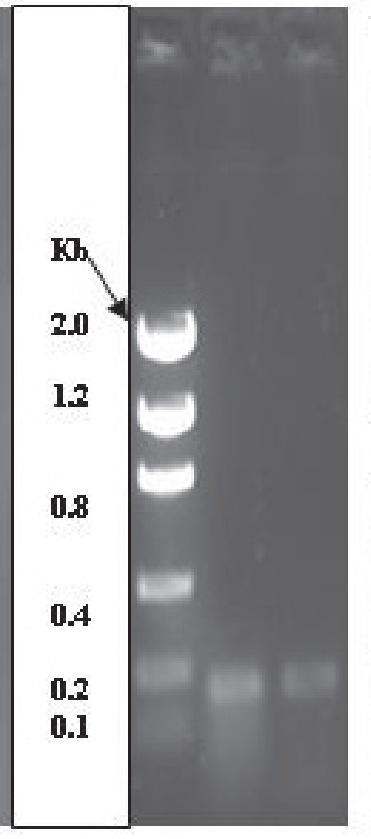

A2 123
Bl
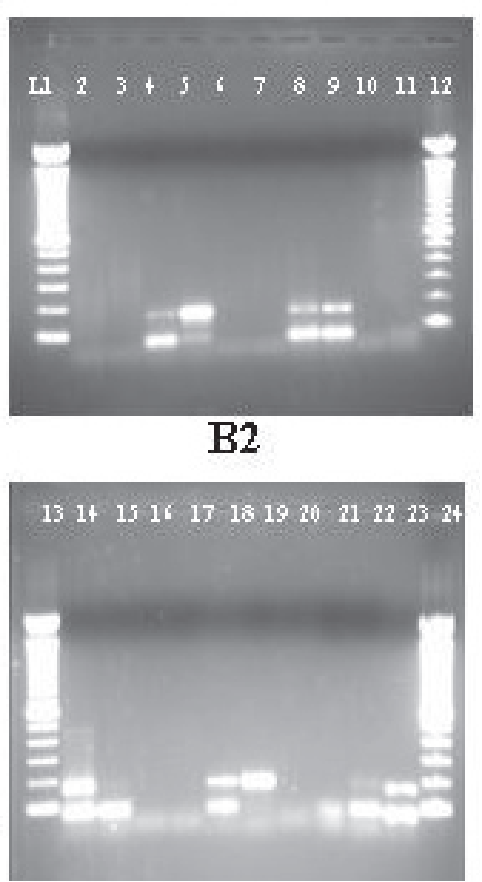

Figure 2 Panel A1. RT-PCR amplicons (Lane 1-3) of CsCl purified dsRNAs (template) obtained from MVX browning mushroom fruit bodies using primers designed from sequences corresponding to our cloned fragments of low molecular weight (LMW) dsRNAs (0.6Kbp) associated with browning and exhibiting highest similarity and homologous to small segments of dsRNA bacteriophage phi-6 (see Table 1). Multiplex (nested) RT-PCR of freshly extracted MVX infected brown skin tissues using primers of Pseudomonas tolaasii (tolaasin primers) and primers deduced from a clone of LMW dsRNA (0.6kbp) of MVX mushrooms. Template dsRNAs of LIV (Lane 5), MBV (Lane 6) and phi-6 (Lane 7) amplified using clones of dsRNAs corresponding to those of phage phi-6. A negative control in which RNA template was omitted (Lane 8). Panel A2. Low titres of amplicons specific to MBV (167 bp) detected consistently in the MVX infected zone compost bed samples in Ireland. Panel B1: [Lanes L1, 12, 13 and 24 molecular weight (100) bp ladder], L 2-3 spawn culture; L-3cereal seeds of spawn; L4-spawned composts; L 6, 7 casing layer; L 8, 9 compost beds ( $1^{\text {st }}$ flush) - primers corresponded to MVX low molecular weight dsRNAs (0.6Kbp, see Table 1) and Lane 9-10 phase II composts; low titres of Mushroom bacilliform virus were also detected in phase II composts (data not shown in this panel). Panel B2: composts beds $L 14$ ( $2^{\text {nd }}$ flush) and $L 15$ ( $3^{\text {rd }}$ flush); $L-16, L 17$ compost beds under healthy looking mushrooms beside browning mushrooms. L 18-raw spent compost (using primers corresponding to clones from MVX low molecular weight bands) and L-19 steam treated spent mushroom compost (multiplex PCR using MVX cloned sequences and phage phi-6 as primers); early compost beds exhibiting barren patches ( $\mathrm{L} 20$, 21) and beds under deformed mushrooms (L 22, 23). 


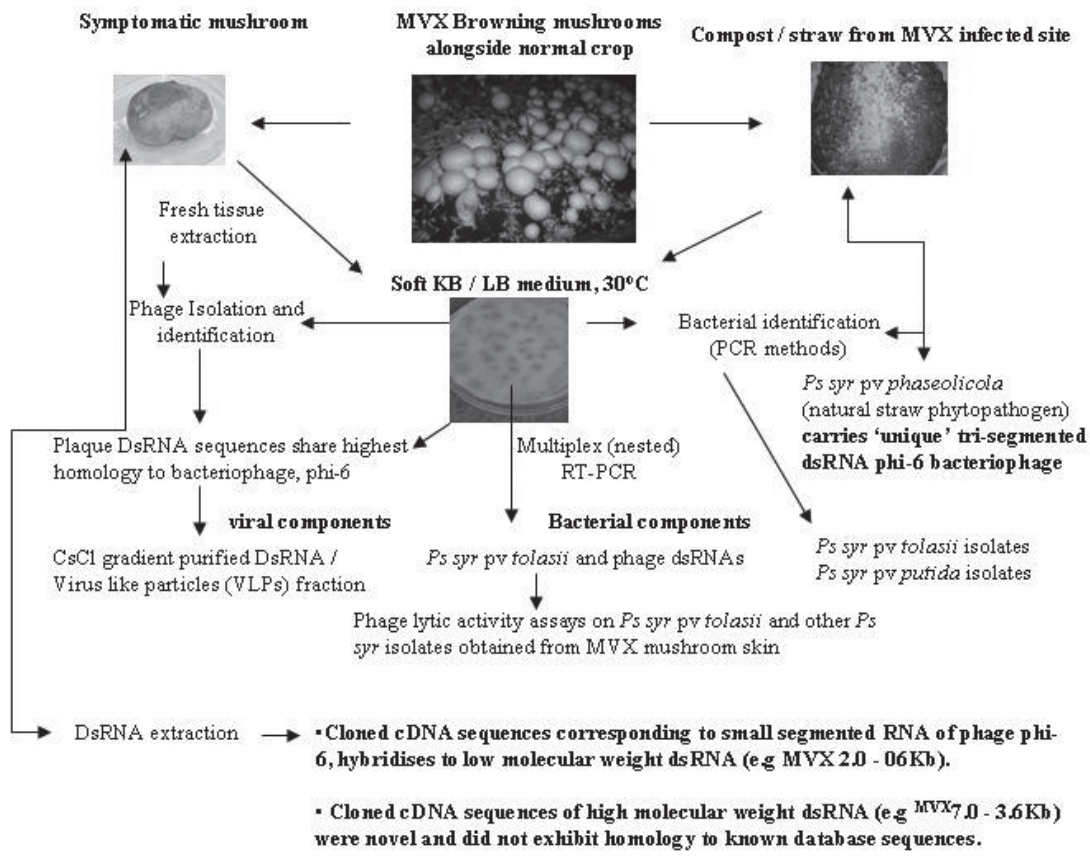

Figure 3 Bacterial and viral components from browning mushrooms infected with Virus $\mathrm{X}$.

(Rao et al., 2003) in the corresponding compost and straw samples taken from the mushroom substrate core within the MVX infected patches or zones.

The fruit body of agaricales fungi are not privy to colonisation by pseudomonads alone; a number of other bacteria have been isolated before on the skin of the mushrooms. Using $16 \mathrm{~S}$ universal primer, we detected a wide range of non-pseudomonad bacteria belonging to the genus such as Acinetobacter or Pedobacter in A. bisporus. Bacillus pumilus and Mycetocola spp. in addition to these two bacteria was also reported by Tsukamoto et al. (2002) in wild mushrooms. Sphingobacterium spp. and Paenibacillus lentimorbus (an insect pathogen of flies/beetles) which we reported in spent composts before (Watabe et al., 2004) were also present in the peripheral skin of the MVX infected fruit bodies; but some of these proved very difficult to culture. Amenable bacterial colonies were sub-cultured in suitable media, stocked for use later and to confirm their molecular identity using (nested) PCR methods via 16sRNA sequencing protocols.

\section{Bacterial plaque identification in the skin of MVX mushrooms}

The protocols described by Sambrook and Russell (2001) were adapted for picking of the isolated plaques from plates. Selected plaques were harvested and plaque dsRNAs were isolated and sequenced using T4-ligated amplification protocol as described before. The sequences were found to share highest homology with a tri-segmented dsRNA of "unique dsRNA carrying" bacteriophage phi-6, whose host, a phytopathogen, Pseudomonas syringae pv. phaseolicola is found in compost straw. BLASTn analyses of cDNA clones of corresponding RNA isolated from plaques indicated that they have a high similarity to the medium or small segment dsRNA elements of this bacteriophage, phi-6. Northern Blot hybridisation experiments indicated that the plaque RNA sequences shared homology with the lower molecular weight (2.0kb-0.6 kbp) MVX (browning) dsRNA bands (Rao et al., 2004). In subsequent experiments (Rao and Nelson, 2005; Rao and Nelson, 2006), we used 'Multiplex (nested) RT-PCR' methods (Bertolini et al., 2003; Lopez et al., 2006) for concurrent detection of multiple pathogens in infected plant/host tissues. Examination of the MVX mushroom skin peel RNA extracts (e.g. see Fig 2 A1-4) with appropriately selected primers for bacterium and the virus revealed the presence of the bacterium, Pseudomonas spp (GenBank accession EF061511-EF061514) and the MVXdsRNA components (of lower molecular weight bands) or those of the phage phi-6 (GenBank accession DQ995400-DQ995402).

\section{Pseudomonas spp. vs bacteriophage sensitivity test}

The presence of bacteriophage on the skin of the MVX infected tissue would imply that if the colonising Pseudomonas spp. is sensitive to phage, a certain level of phage lytic activity can be expected; and this, in a way, can be regarded as a useful self-sanitising feature for reducing pseudomonad populations. On the other hand, if the Pseudomonas spp. exhibit variable resistance to this bacteriophage, this could lead to a selective build up of Pseudomonas strains that could then contribute to the 'browning' symptoms through their lipodepsipeptide secretions. Twenty Pseudomonas syringae strains comprising four distinct races known to commonly occur as straw phytopathogens in the UK were tested via host bacterium and phage transfection methods described by Mindich (personal communication, 2002) for their susceptibility to phage phi- 6 and to the phage particles isolated from diseased mushroom skin described elsewhere. The isolates were found to be sensitive to the phi-6 and also exhibited varying degrees of host (Pseudomonas) co-infectibility with phi-6 bacteriophage. The fluorescent Pseudomonas syringae (pv. tolaasii, 
putida or syringae) isolated from the skin of MVX mushrooms consistently exhibited higher resistance and only a few isolates were sensitive to phage lysis indicating that a selective colonisation could take place on MVX infected mushrooms (Anon., 2004; available from www. dardni.gov.uk/pr2004/pr041933 on request).

\section{Environmental and molecular microbiology of mushroom colonising pseudomonads}

Pseudomonas tolaasii and a number of other variants of Pseudomonas syringae pv. syringae are well known for their ability to undergo 'phenotypical variation', a strategy frequently used by bacteria to survive "disparate environmental conditions" within microcosms of niche (e.g. Rainey, 1989). In addition to alteration in virulence, a number of biochemical properties are also changed during the transition from wild type to phenotypic variant including their qualitative expressions in tolaasin production, varying degrees of off-to brown colour on host $A$. bisporus and in vitro fluorescent colony formation on plates etc (Cutri et al., 1984). Exudates of $A$. bisporus has been demonstrated to have a positive chemotactic response towards both types of Pseudomonas tolaasii and the latter's ability to attach to mycelial surfaces are regarded as crucial steps in early development of browning disease. In an otherwise seemingly identical looking host environment, the wild type (often referred to as 'rough') and phenotype variants ('smooth') have been characterised for their molecular responses to changes in environmental factors (Grewal et al., 1995). Among other interesting observations in particular upon the identification, characterization of a locus within the genetic elements responsible for the expression of pheN lipoprotein, they demonstrated that the amino acid sequence of genetic regulatory elements of pheN have the ability to result in conversions from wild type to phenotype variant.

The pheN gene locus has multiple functions comprising mainly genetic elements (2727 bp ORF) encoding a $83 \mathrm{kDa}$ protein which distinctly conforms to two bacterial 'sensor' and a 'regulator' protein motifs. Their early experiments with an array of combinations of pheN::lacZ constructs revealed that the phenotypical conversion to and the variation of $P$ s. tolaasii is a 'social phenomenon' which implied that these bacterial variants were not only 'interacting' with host (mushroom) mycelial/fruit body surfaces but also 'most certainly responding' to the presence of other microbial cells and most probably to substances produced by other cells together with cell numbers and nutrient status in their growth environment being important determinants for the end game of phenotypical converts: such results can be regarded as early pointers with implications to 'quorum sensing' in microbes! Quite ironically these excitable results have also crossed the 10-year mark inasmuch as the new MVX patch disease have done so with browning symptoms. Moving on from the mushroom skin, our data (unpublished) on mushroom spawn with cereal grains indicated that Pseudomonas syringae pv. syringae strains to be prevalent in early mushroom growth stages and can be detected using syrB and syrD primers used by Bultreys and Gheysen (1999), indicating lipodepsipeptides (syringopeptins or syringostatins) production; these bacterial phytotoxins are known poreforming cytotoxins that act synergistically (lacobellis et al., 1992) promoting passive transmembrane ion flux (Hutchison et al., 1997) and the two genes syrB and syrD conserved in toxin producing strains as single copies in the bacterial genome (Quigley and Gross, 1994) are activated by host (plant) signal molecules. Exudates of A. bisporus can elicit chemotactic responses towards Pseudomonas syringae group of bacterium and can induce specific attachment of pathovars to mycelia, but whether such effects have had preferential selection over strain 'variants' need to be ascertained. A bewildering range of new molecular tools and approaches to soil, rhizosphere and plant microorganisms analysis are available (Cooper and Rao, 2006) and these together with recent updates (e.g. www.cabi.org) on molecular characterization of several plant pathogens including Pseudomonas spp. (Godfrey and Jackson, 2006) when applied to microbemicrobe interactions may provide valuable information on the epidemiology of virulence (the disease severity) and pathogenicity (the ability to cause disease). Molecular characterization of new unknown diseases (e.g. Amasya cherry virus or MVX) and dissection of novel diagnostic molecular elements may reveal intricate networking between community, population, taxonomic and evolutionary significance of microbe-infection-disease and help decipher the genomics, metabolomics and functional activities of the interactive microbes in the niche of interest.

\section{Tolaasin production in MVX mushrooms}

Presumptive pseudomonad bacterial isolates obtained from KB agar incubated with MVX diseased mushroom scrapings were initially screened for their tolaasin production (lipodepsipeptide) precipitation test (see Figure 4.2) in culture plates as described by Wong and Preece (1979). Isolates producing the syringotoxins were further confirmed by GC-MS analysis of the tolaasin. These selected bacteria were further characterised by using PCR assays (Lee et al., 2002) for specific amplification of tolaasingenes and sensitive identification of $P$ seudomonas syringae pv. tolaasii. A rapid mushroom bioassay for browning (see e.g. Figure $4.3 \mathrm{~B}$ ) was performed using procedures modified from Gandy (1968).

Identification of tolaasin in Pseudomonas spp. isolated from MVX infected mushroom skin

A fluorescent Pseudomonas syr pv. tolaasii strain (K59) isolated from the skin of MVX infected mushroom was used as model bacterium for tolaasin production. We extracted the lipodepsipeptide following the procedures described by Nutkins et al. (1991). Separation of compounds extracted from off- or brown-coloured MVX diseased mushroom skin was achieved via Liquid Chromatography-Mass Spectrometry (LC-MS). LCMS detection of the compounds present in the sample was performed using an $\mathrm{LCQ}^{\mathrm{TM}}$ quadruple ion-trap mass spectrometer (Thermo, San Jose, California, USA) utilising electrospray ionisation (ESI) as described by Zhou et al. (2006). Collected fractions of interest were subjected to QToF MS/MS sequencing using a QToF Ultima API mass spectrometer (Waters, Manchester, UK) as described by 


\section{HPLCion trap MS chromatoqram}
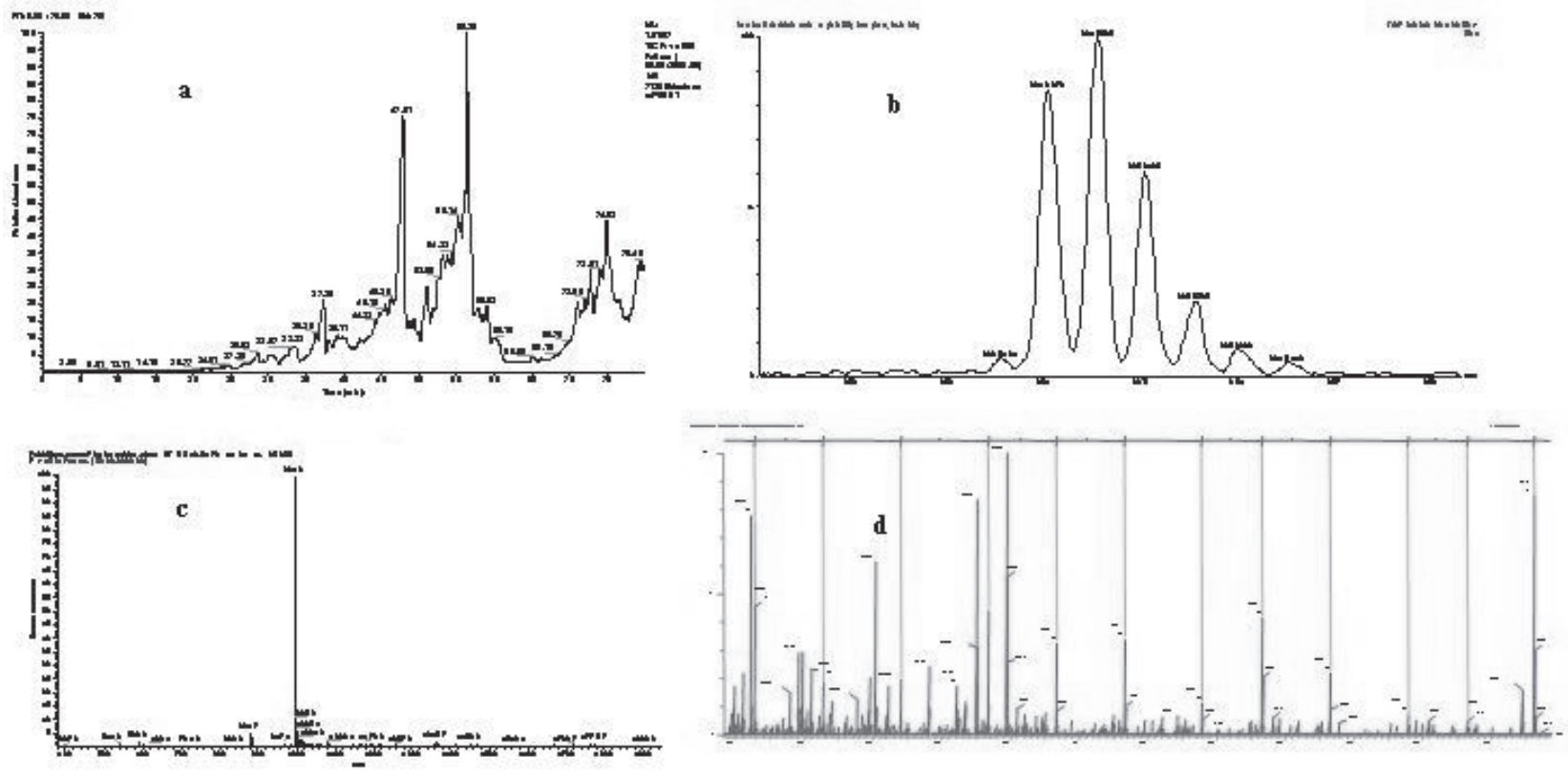

\section{White Line Assay}
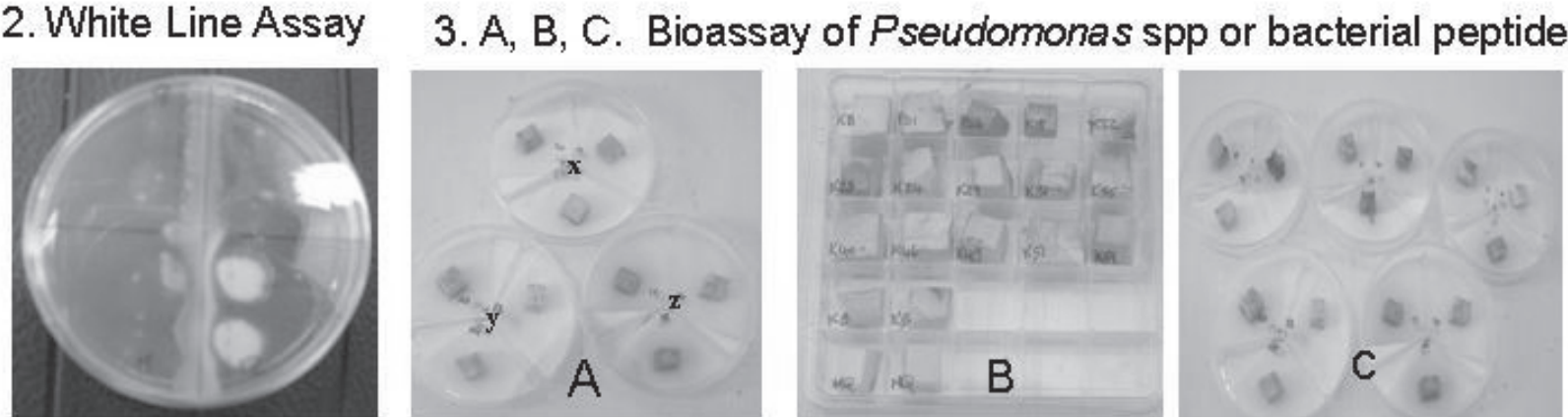

Figure 4 Tolaasin production in MVX mushrooms: 1. a. HPLC ion trap MS chromatogram of a Pseudomonas spp isolated from MVX mushroom skin. The tolaasin peptide elutes with a retention time of 56.38 minutes. b. QToF-MS analysis of the fraction collected corresponding to the 56 min time point on the LC-MS chromatogram. The doubly charged nature of the peak at 994 is clearly seen by the isotopic signals being $0.5 \mathrm{~m} / \mathrm{z}$ apart. c. Corresponding ion trap mass spectrum of the 56.38 minute peak indicating the $[\mathrm{M}+2 \mathrm{H}] 2+$ signal at $\mathrm{m} / \mathrm{z} 994$ for the tolaasin peptide. A single peak signal obtained as QToF MS/MS product ion spectrum ( $\mathrm{m} / \mathrm{z}$ 994). d. QToF MS/MS product ion spectrum for the 994 signal. The ' $y$ ' ion assignment corresponding to the partial amino acid sequence of the tolaasin peptide (PSLVSLVVQLV) was readily established from the generated C-terminal y-ion series. 2. White line (in agar) Assay: Screening of (flourescent) Pseudomonas strains isolated from the skin of MVX infected mushrooms using White-Line-in agar assay (WLA). Tolaasin 'uniquely' forms a dense white line inducing principle (WLIP), against the Lipodepsipeptides (LDP) produced by Pseudomonas reactans (NCPB1311). 3. Tolaasin bioassay: One-day old Agaricus bisporus cubes of cap tissue were scored for the browning and decay relative to a pathogenic Pseudomonas syringae pv tolaasii isolate (NCPPB 2192) as a positive control while uninoculated culture medium (KB) and sterile water treatments (MQ) served as the standard controls. A: $x$-DsRNAs isolated from phi-6, CsCl gradient purified VLPs from MVX mushrooms and MQ (no change). y-Pseudomonas tolaasii (K59) isolated from MVX browning mushrooms with and without phage transfection and purified tolaasin z-Pseudomonas isolated from MVX mushrooms. B: High throughput screening assay of Pseudomonas spp isolated from MVX mushroom skin. C: Screening of known and unknown fractions of Pseudomonas syringae toxins/lipodepsipeptides.

Thompson et al. (2006). The instrument was operated in positive ion "V" optics mode with a spray voltage of $3.5 \mathrm{kV}$ and a cone voltage of $100 \mathrm{~V}$ and for further MS/MS studies the selected precursor ion was fragmented using collision energy of $30 \mathrm{eV}$. Raw MS/MS data were processed using the MaxEnt3 algorithm prior to de novo sequence analysis using Mass Seq software (Waters, Manchester, UK).

A major peak was observed in the LC-MS trace around 56 minutes (Figure 4a-d) which had a corresponding $\mathrm{m} / \mathrm{z}$ value of 994 (Figure 4.1c) indicating a $[\mathrm{M}+2 \mathrm{H}]^{2+}$ precursor. Infusion of this fraction into the QTOF instrument confirmed the double-charged nature of this signal (Figure 4.1b). De-convolution of the multiple charged states for this peptide revealed two possible
$[\mathrm{M}+\mathrm{H}]^{+}$values, one at 1986.12 and the other at 1987.08 . These may be explained by incomplete acid hydrolysis of the glutamine residue to glutamic acid as described by Nutkins et al. (1991). For MS/MS fragmentation no attempt was made to separate the two isotopes formed and rich data suitable for de novo sequence analysis were generated. N-terminal modification of the peptide made initial sequence determination difficult. However, a clear 11 amino acid sequence tag PSLVSLVVQLV, a signatory proteomic fingerprint of tolaasin, was readily established from the generated C-terminal y-ion series and indicative of tolaasin peptides as shown in Figure 4a-d. The QToF MS/MS proteomic sequencing of the ensuing fractions, confirmed the presence of a number of minor peptides 
including a variety of lipodepsipeptides (tolaasins), alongside the major tolaasin peptide $\left(M_{r}\right.$ 1895), known causal agents for browning/discolouration of mushrooms (Rao and Nelson, 2006). Recently, five new structurally modified novel tolaasins have been identified (Basarella et al., 2004). Intensive investigations are in progress at our laboratories in Belfast to identify all Pseudomonas syringae lipodepsipeptides reporting in the extracts of the browning mushroom skin infected with MVX. Unusual variations of mushroom browning caused by novel strains of fluorescent Pseudomonas tolaasii such as NZ17 has been highlighted by the recent studies of Godfrey et al. (2001). It is interesting to note that some of our strains of Pseudomonas syr pv. tolaasii isolated from MVX infected mushroom skin with browning symptoms had a high level of sequence homology to NZ17 strain.

Back to basics: membranes, barriers, entry mechanisms for non enveloped viral forms

With the above in mind, it is prudent to check whether our small collection of Pseudomonas detected in the skin of browning mushrooms would conform to certain basic and well established characteristics expressed by tolaasin producing bacteria and to concurrently explore the fate of dsRNA containing bacteriophage that we co-isolated in the MVX infected mushrooms. Thus, the biological spectrum of activities of lipodepsipeptides produced by Pseudomonas spp. on the skin of mushrooms exhibiting MVX browning symptoms were examined to see if they throw some light on the mechanisms for entry to alien dsRNAs. We set out to compare the physiological activities of lipodepsipeptides (Rainey et al., 1991) to see if there are any differences in their phytotoxic expressions on the mushroom cap tissues. We found (Rao et al., 2006) that the bacterial culture, undifferentiated lipodepsipeptide cocktail as well as the purified fractions of lipodepsipeptides (a) exhibited browning of the tissue, (b) at pH 6.5-7.0 induced haemolytic activity of horse erythrocytes, (c) addition of PEG 1000 (or less) provided protection against tolaasin, which, by itself is a small molecule, indicating of ion-channel forming mechanism in operation on host tissues. A number of syringopeptins and Pseudomonas toxins tested (see Figure 4.3 A, B, C) singly or synergistically exerted disruption of mushroom cell membranes in vitro, but did not show ion channel formation activity. The pore forming ability on host tissue was inhibited by divalent $\mathrm{Zn}^{2+}, \mathrm{Ca}^{2+}$ and $\mathrm{Mg}^{2+}$ metal ions, which were present in physiological abundance in the mushroom substrate and in the mycelial primordia. Inhibition by covalent metal ions on the activity of pore forming haemolytic agents would lead to closure of already formed pores but in tandem; these collaterals could lead to an 'open and shut' mechanism offering a plausible means of entry to unwarranted elements such as dsRNAs into the membrane. Given that, did 'alien' dsRNAs (such as phi-6) detected on the skin of MVX browning mushrooms or even in spawn mycelia, gain/sneak entry? We have no direct evidence, but the circumstantial probability does seem to exist. Structurally modified tolaasin peptides on the skin of mushrooms can be the result of co-colonisation by tolaasin detoxifying non-pseudomonads (Tsukamoto et al., 2002) and by either other mixed populations of
Pseudomonas tolaasii variants or early colonisers such as Pseudomonas syringae species detected in cereal seeds used for mushroom spawn. Such activities are potentially capable of eliciting a differential response in interactive host $A$. bisporus cells. Unequivocal investigations are required to clarify interactive chemo-microbial responses and/or quorum sensing effects that may possibly be operative in the microcosm environments during early mushroom developmental stages. A recent study by Duffy et al. (2006) using Pseudomonas syringae as hosts and bacteriophage phi- 6 as model demonstrated the possibility of niche expansion under varied ecological conditions and may favour host shifts in RNA viruses.

\section{Molecular viral ecology}

The presence of homologous single stranded virus such as MVX in mushrooms is an intriguing observation deduced from the homology match to one of the dsRNAs (Adie et al., 2004) as well as from our results in early compost and whole mushroom (see Table 2). Low levels of 'homologous' mushroom viruses such as Mushroom bacilliform viruses (MBV) were also detected in $A$. bisporus spawned compost and diseased fruiting bodies (see Figure 2). In the case of animal viruses, early classical examples such as fowl plague virus have provided evidence as to how new viruses emerge through incomplete viral particles formation in conjunction with homologous 'helper viruses' in the vicinity of a new infection either by virions, virus like particles or dsRNAs. Such particles are known to interfere with the normal multiplication of homologous standard virus, a step that may play a major role in the evolution or emergence of a new viral disease (Huang and Baltimore, 1970, Nature). Bearing in mind that crossing the cellular membrane is a key step in the infectious life cycle of all viruses, it is imperative that one looks around to contemporaneous models. Whereas the understanding of 'enveloped' virus entry via membrane fusion has well advanced for mammalian viruses (e.g. see reviews of Harrison, 2005; Keilian, 2006), the mechanisms of entry for non-enveloped virus, virus like particles or dsRNAs are still in its infancy. Noteworthy of developments in comparative eukaryotic and prokaryotic system host cell vis-à-vis viral nucleic acid entry mechanisms using $P s$ syringae - phage (phi-6) models are those published by Dennis $\mathrm{H}$ Bamford et al. in Finland (e.g. Porannen et al., 1999), and in unicellular fungi yeast (e.g. Caston et al., 1997) for replication of capsidated RNAs. RNA viruses are prone to mutations during their attachment to proteins that change or expand their host ranges and may well offer in part, a plausible explanation as to why some $\sim 50$ RNA viruses including human immunodeficiency virus, Ebola virus, SARS coronavirus and several hantaviruses have shifted from nonhuman hosts to humans since World War II (e.g. Morse, 1993; Brault et al., 2004). Results from a recent study (Duffy et al., 2006) using Pseudomonas syringae hosts and bacteriophage phi- 6 as model also addresses an important step in viral emergence critical for predicting varied environmental conditions that may favour host shifts in RNA viruses and thereby for disease emergence in novel or 'unselected' hosts. Given the current understanding of $\mathrm{MVX}$ disease complex, regardless of the identities of the multiple viruses (presumed present 
on the basis of dsRNAs) in the host, a competitiveness, driven predominantly by genetically imposed 'costs' can thus be expected to play an equitable role for niche/novel host selection mechanisms.

Last but not the least, the studies of Professor Romaine et al., USA (e.g. Romaine and Goodin, 2002) on mushroom La France virus is a classical example of how complex the capsidation and non enveloped dsRNAs process are for packaged full viral particles. This group have been highly interactive partners to MVX research in the UK and in Europe. Many of their molecular experiences with La France have been incorporated into MVX investigations including techniques for separation of dsRNAs, RNA sequencing and RT-PCR analyses. More recently, his group's successful development of a fruiting body tissue method for efficient Agrobacterium mediated transformation of $A$. bisporus offers new prospects for genetic manipulation of this commercially important mushroom species (e.g. Chen et al., 2000, 2004; Foster et al., 2004; Romaine, 2003; Romaine et al., 2004).

\section{Presumptive, defective virus-like particle formations}

Isopycnic $\mathrm{CsCl}$ gradient fractions prepared from mushrooms symptomatic of MVX disease yielded dsRNAs or virus like particles (VLPs) and these were used (Rao et al., 2004) as templates for Reverse transcription (RT-) PCR analyses (see also Figure 2 A1). This could be the first lead for 'defective virus-like particle' (VLPs) formation in the MVX complex. Amplicons obtained from $\mathrm{CsCl}$ purified dsRNAs or VLP fractions exhibited small nucleotide variations in hairpin regions (10-50) crucial for encapsidation. It may be worthwhile to overview our findings to those of the new viruses with presumed fungal aetiology such as the Amasya cherry disease. Dr Bob Coutts group at the Imperial College, London, (Kozlakidis et al., 2006) recently achieved molecular characterization of two new viruses via sequencing of two largest (novel) dsRNAs (L3, L4) of ACD whose translated RNA dependent RNA polymerase (RdRP) regions had high similarity with other members of the Totoviridae. However, the sequences of other novel dsRNAs (L1 and L2) do not code for RdRPs and thus justify the novel status of these viruses until their mode of replication and relationships with L3 and L4 DsRNAs are fully established. We have aligned our sequences obtained on RdRp translations of the dsRNA (size), which show similarity to those of the published sequences (Kozlakidis etal., 2006). Interestingly, BLASTn alignments of deduced RdRP (RNA dependent RNAPolymerase) sequences of MVX-mushroom dsRNAs (Rao et al., 2006) exhibited highest similarity also with RdRPs of PRD1 phage (host: Salmonella typhimurium), fowl plague virus and to those of dsRNA carrying Cryptosporidium baileyi (poultry biotype), some of which are known to occur in chicken litter, an ingredient of the compost for mushroom cultivation. In contrast to ACD or CCRD viruses of the cherry, with MVX, powerful EM analyses have failed to detect the virions. An overview of the molecular analyses carried out in Warwickhri, UK or in the Netherlands and here in Northern Ireland reveal that further rigorous studies are yet required to fully ascertain the nature as well as the full molecular dimensions of the novel MVX dsRNAs and their replication mechanisms.

The Dutch findings suggest, in general, that larger MVX dsRNAs lacked a positive relationship with an aberrant phenotype and that the four smaller MVX diagnostic segments were always present together indicating that they might represent a virus; but they were not sure whether a virus was the causal agent for the (browning) symptom or just a result of an unknown stress. Recent evidence obtained in our laboratory (see Fig 4) at Belfast when taken together with the background literature suggest that plant pathogenic Pseudomonas and more specifically their (bacterial) peptides probably exulted significant environmentally governed 'stress effects' culminating to off - or brown-colour response in the host mushrooms cap tissues rather than the four smaller MVX dsRNAs implicated in the browning symptoms within the MVX disease complex. For instance, in our preliminary bioassays (Fig 4.3 A, B or C), with the exception of bacterial peptide extracts or the bacterial cultures and culture filtrates, neither the MVXdsRNAs nor dsRNA containing phage phi- 6 produced the off- brown colour on mushroom cubes or whole fruiting bodies. Northern hybridisation analyses of smaller MVX dsRNAs obtained from browning mushroom samples in Ireland exhibited high homology to probe sequences of dsRNA carrying (Pseudomonas) bacteriophage phi-6 (Rao et al 2004). Future research should unequivocally extend Northern blot hybridisation using phi- 6 sequences as a probe on the smaller MVX dsRNAs of UK and Holland samples and ascertain as to whether these smaller dsRNAs infect mushrooms and clarify of their being limited (or not) to the (colonising) bacteria on the mushroom skin; all of which could prove critical to this hypotheses (Romaine, personal communication).

\section{Current perspectives and issues in molecular biology of MVX}

Whatever the dsRNAs sequences have revealed thus far about new emerging mushroom virus (X) disease, and of the viral aetiology of the associated symptoms in the disease complex, it remains as 'enigmatic' as it was when it all started some 10 years ago in the spring/autumn of 1996. A number of current issues for deciphering the molecular biology of this elusive and devastating mushroom virus $X$ disease remain to be thoroughly explored. Despite the exchange of facts, opinions, comments and questions between the various worldwide groups working on decoding the secrets of molecular fingerprints of dsRNAs of MVX disease, in the ensuing decade of its first sightings in a British farm, some fundamental and outstanding issues still remain to be addressed. These include the lack of consistency in synchronous banding patterns to symptoms and the requirement of full-length sequences of the dsRNAs uniquely linked to the MVX disease. DsRNA resolutions on agarose were not always congruous to those obtained on conventional polyacrylamide gel electrophoresis protocols. Within the overall generic theme of ligation and primer walking strategies applied for cloning and sequencing of dsRNAs, variant approaches in application 
were apparent in the UK, The Netherlands and by us here in Northern Ireland.

Symptomatic, sample and geographical variations of dsRNAs can be expected in viral diseases. However, different laboratory practices may have also contributed in terms of the variations in dsRNA patterns and their sequences. In order to have a better understanding to sample/site/farm/regional variations, the experimental and technical elements of concern may also need to be either minimised or if possible eliminated while studying a complex viral disease such as MVX. For instance, many of the MVX dsRNAs are regarded as novel, and corresponding genomic copies may apparently not be readily available; and as such, these dsRNAs appear to be the only source for the novel nucleic acids/sequencing analyses (via cloning) in a given site/sample. Given the circumstances, some minor but significant technical issues may need to be carefully assessed for analyses of the novel MVX dsRNAs. The 26 or so dsRNAs present themselves in variable titers (Grogan et al., 2003) and more so, not all ranges of dsRNAs can be visualised (Figure 1) by a single type or concentration of agarose or polyacrylamide matrix. In our samples, higher concentrations of dsRNAs (either through the usage of larger quantities of mushroom skin tissue extracts or via overloading gels) and longer exposure under UV in excess Ethydium Bromide (EtBr) staining (see Fig 1) was necessary to visualise particularly the lower molecular weight dsRNAs ( ${ }^{\mathrm{Mv}} 2.0,{ }^{\mathrm{mvx}} 1.8,{ }^{\mathrm{mvx}} 0.8$ and $\left.{ }^{\mathrm{mvx}} 0.6\right)$. The observation that these dsRNAs appear to be confined to the mushroom skin (Sonnenberg and Lavrijssen, 2004) when taken together with our data (Rao et al., 2004) in regard to the occurrence of high populations of bacteria (Pseudomonas spp.) and its counterpart bacteriophage (viral) dsRNA in the skin tissues (e.g. see Fig 2, A4-1) may in part, help explain a) the higher volume of tissues required for visualisation under UV as opposed to traditional mycoviral dsRNAs which present themselves in relative abundance in infected mushroom tissues and b) the off-colour or browning of mushrooms is more bacterium linked than those expected of viruslike symptoms (Romaine, personal communication). Regardless of the identity of these smaller dsRNAs and whether or not they are the etiologic agent of browning MVX mushrooms, they are being visualised at a higher $\mathrm{UV} / \mathrm{EtBr}$ exposure during the molecular analyses and raise concerns.

UV damage to (agarose/EtBr stained) gel recovered dsRNA is well known to culminate often into significant shifts in sequencing data. However, such UV-induced effects after cloning by far, might not affect homology comparisons for 'known genomes' or their nucleic acid sequences of a given species. To this end, the factors that potentially contribute to errors in deductions of homology matches for unique/novel sequences (e.g. low molecular weight MVX dsRNAs) have to be tactfully addressed as far as is possible, until such time the identity of all novel dsRNAs are unequivocally established. UV-induced photoproducts to nucleic acids are common and varies from species to species but most UV induced damages are normally repaired by the 'host' in short turn-over periods (e.g. Takata et al., 2002). Insofar as the novel MVX
dsRNAs present in a 'new host' (mushroom) is concerned, the multiple viruses constituted in the MVX disease complex and their replication modes are yet unknown. Furthermore, the fate of UV damage to unencapsidated dsRNA during technical operations relatively remains unquantified in terms of potential sequence shifts. Initial cloning and sequencing of disparate dsRNAs of unknown and/or novel origin can be achieved via other alternative approaches (e.g. PAGE, staining and visualised by SybRGreen/Gold, silver stains etc.) that are relatively regarded as less detrimental to nucleic acids and need careful consideration.

In the light of the complicated nature of the MVX, it may be worthwhile to evolve a consensus based standardisation of various protocols incorporating the essential steps of all laboratory techniques for obtaining meaningful and unequivocal comparisons of data on MVX disease. As Romaine et al. (2002) have suggested future work requires a rigorous testing of cause and effect relationship; he also has raised a number of interesting propositions: are the dsRNAs exclusively associated with anomalies? Or will an exhaustive molecular search reveal the presence of dsRNAs at higher frequency in healthy tissues? Do the current sets of symptoms match the dsRNA profiles? Last, but not the least, Professor Romaine who has encountered a number of circumstantial evidences gathered for La France virus, proposes strongly to undertake studies involving the expression of viral sequences (in this case MVX) in A. bisporus following their introduction by transfection or genetic transformation using methods developed with Agrobacterium tumefaciens (e.g. Romaine, 2002; Romaine et al., 2003, 2004; Foster et al., 2004).

Genomics for understanding host-pathogen interactions Drawing parallels with other hosts such as plants (e.g. Arabidopsis) and mamamalian (e.g. Human) systems, and other well studied Basidiomycete fungi itself such as Coprinus cinereus, Schizophyllum commune, the lack of substantive genome information of the host Agaricus bisporus, white mushroom fungi is a major set back while studying host-pathogen interactions. Attempts to pursue $A$. bisporus genome sequencing scheme has not materialised in the past. With the knowledge that there is only a partial genomic data available for white button mushrooms, it is our view that Agaricus bisporus mushrooms by virtue of their global commercial status as well as being a modest $\sim 38 \mathrm{MB}$ genome size, relatively a 'shorty' compared to some of gigantic-genomes of mammals or plants, deserves to be considered as a strong candidate for genome mapping in the nearest future involving international consortia of mushroom research groups.

\section{Enigmatic optimism for the future}

If we took a few steps back from the maze of molecular biology surrounding the unraveling of cryptic viruses surmounted by dsRNAs, their size, numbers, nucleotide sequences etc and looked elsewhere for inspiration, solving mathematical theorems comes in handy. Pierre de Fermat was a French lawyer and government official most remembered for his work in number theory; notably, 
Fermat's Last Theorem unwittingly founded the science of calculus. Fermat died in 1665 and today we think of Fermat as perhaps the most famous number theorist who ever lived. It is beyond anybody's comprehension that he was a lawyer and only an amateur mathematician. In fact he published only one mathematical paper in his life and that too was an anonymous article written as an appendix to a colleague's book. Fermat's Last Theorem states that $x^{n}+y^{n}=z^{n}$ has no non-zero integer solutions for $x$, $y$ and $z$ when $n>2$. Fermat wrote "I have discovered a truly remarkable proof which 'this margin is too small' to contain". After nearly 350 years, Andrew Wiles of Great Britain in collaboration with his former student Richard Taylor at Princeton, NY, USA, in 1995 helped complete the proof to the solution. In his article in Scientific American, Wiles likened the trials and tribulations of the many enduring mathematicians over the time to climbing Everest: 'To some extent, proving Fermat's Theorem was like when one climbs Everest and falls short of it by 100 yards, one has not climbed Everest'. World over there are many unresolved infections of viral nature still under either intense scientific debate or demanding scrutiny. Mushroom researchers perhaps have been left to ponder over an enigmatic molecular equivalent of Fermat's theorem: $(\text { DsRNAs })^{n}+\left(\right.$ viruses $^{n}=M V X^{n}$ when $n>2$, where $X=$ ? Some of us have a notion of what mushroom viruses $(\mathrm{MV})$ are and as to what $\mathrm{X}$ could be. Do we have proof of what $X$ is (or are)? Of course, this essay is 'marginally too small' for us to contend with. It may not take centuries to unravel MVX, but we have our work cut out.

\section{References}

Adie, B., Choi, I., Soares, A., Holcroft, S., Eastwood, D.C., Mead, A., Grogan, H. M., Kerrigan, R. W., Challen, M. and Mills, P. R. (2004). MVX disease and double-stranded RNA elements in Agaricus bisporus. In Mushroom Science XVI Science and Cultivation of Edible and Medicinal Fungi. Romaine, C.P. Keil, C. B., Rinker, D. L. and Royse, D. J. (eds), Penn State, USA 411-420.

Anon (2004). Development of rapid methods for bacterial, fungal and viral pathogens of mushrooms. Final report Available from www.dardni.gov.uk/pr2004/pr041933

Arakawa, M., Nakamura, H., Uetake, Y. and Matsumoto, N. (2002). Presence and distribution of double-stranded RNA elements in the white root rot fungus Rosellinia necatrix. Mycoscience 43, 21-26.

Bassarello, C., Lazzaroni, S., Bifulco, G., Lo Contore, P., lacobellis, N.S., Riccio, R., Gomez-Paloma, L. and Evidente, A. (2004). Tolaasins A-E, five new lipodepsipeptides produced by Pseudomonas tolaasii. J. Natural Prod. 67, 811-816.

Bertolini, E., Olmos, A., Lopez, M.M., Cambra, M. (2003). Multiplex nested reverse transcription polymerase chain reaction in a single tube for sensitive and simultaneous detection of four RNA viruses and Pseudomonas savastanoi. in olive trees. Phytopathology 93, 286292.

Brault, A.C., Powers, D., Ortiz., J.G., Estrada-Franco, R. and Navarro-Lopez. (2004). Venezuelan equine encephalitis emergence: enhanced vector infection from a single amino acid substitution in the envelope protein. Proc. Natl. Acad. Sci. USA. 101, 11344-11349.

Brodey, C.L., Rainey, P.B., Tester, M. and Johnstone, K. (1991). Bacterial blotch disease of the cultivated mushrooms is caused by an ion channel forming lipodepsipeptide. Mol. Plant Micr. Interact. 4, 407-411.

Bultreys, A. and Gheysen, I. (1999). Biological and molecular detection of toxic lipodepsipeptide-producing Pseudomonas syringae strains and PCR identification on plants. Appl. Environ. Microbiol. 65, 1904-1909.

Cashdollar, L.W., Esparza, J., Hudson, G.R., Clunelo, R., Lee, P.W.K. and Joklik, W.K. (1982). Cloning the double-stranded RNA genes of reovirus:sequence of the cloned S2 gene. Proc. Nat. Acad. Sci. USA 79, 7644-7648.

Caston, J.R., Trus, B.L., Booy, F.P., Wickner, R.B., Wall, J.S. and Steven, A. C. (1997). Structure of L-A Virus: A specialized compartment for transcription and replication of double-stranded RNA. J. Cell Biol. 138:975-985.

Chen, X., Stone, M., Schlagnhaufer, C. and Romaine, P. (2000). A fruiting body tissue method for efficient Agrobacterium-mediated transformation of Agaricus bisporus. Applied Environ. Microbiol. 66, 4510-4513.

Cooper, J.E. and Rao, J.R. eds., (2006). Molecular approaches to soil, rhizosphere and plant microorganism analysis. CABI, Oxfordshire, UK. www.cabi.org

Coutts, R.H.A. and Livieratos, I.C. (2003). A rapid method for sequencing the $5^{\prime}$ - and 3 '-termini of double-stranded RNA viral templates usig RLM-RACE. J. Phytopathol. 151, 525-527.

Coutts, R. H. A., Covelli, L., Di Serio F., Citir, A., Acikgoz, S., Hernandez, C., Ragozzoino, A. and Flores, R. (2004). Cherry chlorotic rusty spot and Amasya cherry diseases are associated with a complex pattern of mycoviral-like double-stranded RNAs II. Characterization of a new species in the genus Partitivirus. J. Gen. Virol. 85, 3399-3403.

Covelli, L., Coutts, R.H.A., Di Serio F., Citir, A., Acikgoz, S., Hernandez, C., Ragozzoino, A. and Flores, R. (2004). Cherry chlorotic rusty spot and Amasya cherry diseases are associated with a complex pattern of mycoviral-like double-stranded RNAs I. Characterization of a new species in the genus Chrysovirus. J. Gen. Virol. 85, 3389-3397.

Clarke, I.N. and McRae, M.A. (1981). A rapid and sensitive method for analyzing the genome profiles of field isolates of rotavirus. J Virol. Methods 3, 261-269.

Cutri, S.S., Maccaulay, B.J. and Roberts, W.B. (1984). Characteristics of pathogenic non-fluorescent (smooth) and non-pathogenic (rough) forms of Pseudomonas tolaasii and Pseudomonas gingeri. J. Bacteriol. 57, 291-298.

Dennehy, J.J., Freidenberg, N.A., Holt, R.D. and Turner, P.E. (2006). Viral ecology and maintenance of novel host use. Am. Nat. (in press).

Duffy, S., Turner, P.E. and Burch, C.L. (2006). Pleiotropic costs of niche expansion in the RNA bacteriophage phi6. Genetics 172, 751-757.

Fekete, C., Giczey, G., Papp, I., Szabo, L. and Hornok, L. (1995). High Frequency occurrence of virus-like particles with double-stranded RNA genome in Fusarium poae. FEMS Microbiol. Lett. 131:295-299. 
Foster, G.D., Burns, C., Bailey, A., Challen, M., Elliot, T. and Burton, K.S. (2004). Tools for Agaricus and Coprinus transformation and analysis of gene expression. In Mushroom Science XVI Science and Cultivation of Edible and Medicinal Fungi. Romaine, C.P. Keil, C. B., Rinker, D. L. and Royse, D. J. (eds), Penn State, USA. 59-65.

Fukusho, A., Yu, Y., Yamaguchi, S. and Roy, P. (1989). Completion of sequence of bluetongue virus serotype 10 by the characterisation of a structural protein, VP6, and a non-structural protein NS2. J. Gen. Virol. 70, 1677-1689.

Gaze, R.H. (1999). Virus in disguise? Mushroom J. 590, 17-19.

Gaze, R.H., Calvo-Bado, L., Challen, M.P., Adie, B. and Romaine, P. (2000). A new virus disease of Agaricus bisporus? In Science and cultivation of Edible fungi. Van Griensven, L. J. L. D. (Ed). Balkema Publishers, Rotterdam, The Netherlands, 701-705.

Gaze, R.H. (2000). Virus X revisited. Mushroom J. 608, 12-15.

Gaze, R.H. (2001). Virus X An update. Mushroom J. 615, 11-13.

Gaze, R.H. (2002a). The many small steps to getting virus X. Mushroom J. 621, 11-13

Gaze, R.H. (2002b). Virus $X$ and compost production. Mushroom J. 635, 13-14.

Gillings, M.R., Tesoriero, L.A. and Gunn, L.V. (1993). Detection of double-stranded RNA and virus-like particles in Australian isolates of Pythium irregulare. Plant Pathol. 42, 6-15.

Godfrey, S.A.C., Marshall, J.W. and Klena, J.D. (2001). Genetic characterization of Pseudomonas 'NZ17'- a novel pathogen that results in a brown blotch disease of Agaricus bisporus. J. Appl. Microbiol. 91, 412-420.

Godfrey, S.A.C. and Jackson, R.W. (2006). Molecular characterization of bacterial plant pathogens. In molecular approaches to soil, rhizosphere and plant microorganism analysis (Cooper, J. E. and Rao, J. R eds), CABI, Oxfordshire, UK www.cabi.org

Goodin, M.M., Schlagnhaufer, B., Weir, T. and Romaine, C.P. (1997). Characterization of an RNA dependent RNA polymerase activity associated with La France isometric virus. J. Virol. 71, 2264-2269.

Grewal, S.I.S., Han, B. and Johnstone, K. (1995). Identification of a locus which regulates multiple functions in Pseudomonas tolaasii, the cause of brown blotch disease of Agaricus bisporus. J. Bacteriol. 177, 4658-4668.

Grogan,H.M., Adie, B.A.T., Gaze, R.H., Challen, M.P. and Mills, P.R. (2003). Double-stranded RNA elements associated with the MVX disease of Agaricus bisporus. Mycol. Res. 107:147-154.

Grogan, H M. (2006). Mushroom Virus X (MVX): A new disease of mushrooms. The Society of Irish Plant Pathologists, Autumn Scientific Meeting, 05/09/2006, Co. Kildare. Abstract.

Hansen, D.R., van Alfen, N.K., Gillies, K. and Powell, W.A. (1985). Naked dsRNA associated with hypovirulence of Endothia parasitica is packaged in fungal vesicles. J. Virol. 66, 2605-2614.
Harmsen, M.C., van Griensven, L.J. L.D. and Wessels, J.G.H. (1989). Molecular analysis of Agaricus bisporus double-stranded RNA. J. Virol. 70, 1613-1616.

Harrison, S.C. (2005). Mechanism of membrane fusion by by viral envelope proteins. Adv. Virus Res. 64, 231261.

Hillman, B.I., Halpern, B.T. and Brown, M.P. (1994). A viral dsRNA element of the chestnut blight fungus with a distinct genetic organisation. Virology 210, 241-250.

Hollings, M. (1962). Viruses associaaated with a die-back disease of the cultivated mushroom. Nature 196, 962965.

Huang, A.S. and Baltimore, D. (1970). Defective viral particles and viral disease processes. Nature 226, 325-327.

lacobellis, N.S., Lavermicocca, P., Grgurina, I., Simmaco, M. and Ballio, A. (1992). Phytotoxic properties of Pseudomonas syringae pv. syringae toxins. Mol. Plant Pathol. 40, 107-116.

Inglis, P.W. and Valederas-Inglis, M.C. (1997). Rapid isolation of double-stranded RNAs from entomopathogenic species of the fungus Paecilomyces using commercial minicolumn system. J. Virol. Methods 67, 113-116.

Jones, P., Martin, M. (2003). A review of the literature on the occurrence and survival of pathogens of animals and humans in green compost. The Waste and Resources Action Programme, Oxon. UK (www.wrap.org.uk).

Kozlakidis, Z., Covelli, L., Di Serio F., Citir, A., Acikgoz, S., Hernandez, C., Ragozzoino, A., Flores, R. and Coutts, R.H.A. (2006). Molecular characterisation of the largest mycoviral like double-stranded RNAs associated with Amasya cherry disease, a disease of presumed fungal aetiology. J. Gen. Virol. 87, 3113-3117.

Kielian, M. and Rey, F.A. (2006). Virus membrane proteins: more than one way to make a hairpin. Nat. Rev. Microbiol. 4, 67-76.

Lane, D.J. (1991). 16S/23S sequencing. In Nucleic acid Techniques in Bacterial Systematics. Stackebrandt, E. and Goodfellow, M. (eds). Chichester, UK, John Wiley.

Lee, H.I, Jeong, K. S. and Cha, J. S. (2002). PCR assays specific and sensitive detection of $P$ seudomonas tolaasii, the cause of brown blotch disease of mushrooms. Lett. Appl. Microbiol. 35, 276-280.

Lopez, M.M., Bertolini, E., Marco-Noales, E., Llop, P. and Cambra, M. (2006). Update on molecular tools for detection of plant pathogenic bacteria and viruses. In Molecular Diagnostics-Techniques and Applications. Rao, J. R. Fleming, C.C. and Moore, J. E. (eds). Horizonpress, UK. www.horizonbioscience.com 1-47.

Magae, Y. and Hayashi, N. (1999). Double-stranded RNA and virus-like particles in the edible basidiomycete Flammulina velutipes (Enokitake). FEMS Microbiol. Lett. 180, 331-335.

Marino, R., Saksena, K.N., Schuler, M., Mayfield, J.E. and Lemke, P.A. (1976). Double-stranded ribonucleic acid in Agaricus bisporus. Appl. Environ. Microbiol. 31, 432-438.

Moore, E.R.B., Mau, M. and Arnscheidt A. (1996). The determination and comparison of gene sequences of species of the genus Pseudomonas (sensu stricto) 
and estimation of the natural intrageneric relationships. Syst. Appl. Microbiol. 19, 478-492.

Morris, T.J. and Dodds, J.A. (1979). Isolation and analysis of double-stranded RNA from virus-infected plant and fungal tissue. Phytopathol. Z. 69, 854-858.

Morse S.S. (1993). Emerging viruses. Oxford University Press, New York.

Nutkins, J.C., Moltshire-Smith, R.J., Packman, L.C., Brodey, C L., Rainey, P.B., Johnstone, K. and Williams, D.H. (1991). Structure determination of Tolaasin, an extracellular Lipodepsipeptide produced by the mushroom pathogen Pseudomonas tolaasii Paine. J. Am. Chem. Soc. 113, 2621-2627.

Passmore, E.L. and Frost, R.R. (1974). The detection of virus-like particles in mushrooms and mushroom spawns. Phytopathol. Z. 80, 85-87

Passmore, E.L. and Frost, R.R. (1979). The detection and occurrence of virus-like particles in extracts of mushroom sporophores. Phytopathol. Z. 95, 346-363.

Porannen, M.M., Daugelavicius,R., Ojala, P.M., Hess, M.W. and Bamford, D.H. (1999). A novel virus-host cell membrane interaction: Membrane voltage dependent endocytic-like entry of bacteriophage phi-6 nucleocapsid. J. Cell. Biol. 147, 671-681.

Quigley, N.D. and Gross, D.C. (1994). Syringomycin production of Pseudomonas syringae pv. syringae: conservation of syrB and syrD genes and activation of phytotoxin production by plant signal molecules. Mol. Plant Microbe Interact. 7, 78-90.

Rainey, P. B. (1989). PhD. Thesis. University of Canterbury, Christchurch, New Zealand.

Rainey, P.B., Brodey, C.L. and Johnstone, K. (1991). Biological properties and spectrum of activity of tolaasin, a lipodepsipetide toxin produced by the mushroom pathogen Pseudomonas tolaasii. Physiol. Mol. Plant Pathol. 39, 57-70.

Rao, J.R., Nelson, D., Lafferty, N., Moore, J.E., Millar, B.C., Xu, J and Watabe, M. (2003). Biohazards and ecotoxicological considerations for landspreading of spent compost wastes. Commun. Biol. Applied Agriculture 68 (4b), 219-225.

Rao, J.R., Romaine, C.P., Mindich, L., Moore, J.E., Nelson, D.W.A. and Lafferty, N.M. (2004). Mushroom browning syndrome in Agaricus bisporus linked to phi-6 bacteriophage-related dsRNAs and surrogate bacterial host Pseudomonas syringae pv. tolasii. Proceedings of the XVIth International Congress on the Science and Cultivation of Edible and Medicinal Mushrooms and 17th North American Mushroom Conference, pp 43-44.

Rao, J.R., Nelson, D.W. A. (2005). Molecular relationships between dsRNAs of phi- 6 bacteriophage, Pseudomonas syringae pv. tolasii and mushrooms virus $\mathrm{X}$ browning related dsRNAs. Society of General Microbiology Meeting (1-4 April 2005), Edinburgh, UK. Abstract. http://www.sgm.ac.uk

Rao, J.R., Nelson, D.W. A. (2005). Molecular interactions between wheat straw phytopathogen Pseudomonas syringae bacteriophage (phi-6) dsRNAs and the host mushrooms during browning disease development. In Proceedings International Plant Biology Meeting,
Seattle, USA (14-18 July 2005). Poster and oral presentation. Abstract www.aspb.org

Rao, J.R., Nelson, D.W.A. (2005). Identification of browning related bacterial components in mushroom viral patch disease. Society of General Microbiology Meeting (Irish branch) 8-9 September 2005. Abstract. http://www.sgm.ac.uk

Rao, J.R., Nelson, D.W.A. and McClean, S. (2006). Pseudomonasspecies, tolaasin peptides, bacteriophage phi-6 and dsRNAs identified in the skin of off- or browncoloured Agaricus bisporus affected by mushroom virus $X(M V X) .158^{\text {th }}$ Meeting, University of Warwick, UK. Abstract. http://www.sgm.ac.uk

Revill, P.A. and Wright, P.J. (1997). RT-PCR detection of dsRNAs associated with La France disease of the cultivated mushroom Agaricus bisporus (Lange) Imbach. J. Virol. Methods 63, 17-26.

Romaine, C.P. and Schlagnhaufer, B. (1989). Prevalence of double-stranded RNAs in healthy and La France disease affected basidiocarps of Agaricus bisporus. Mycologia 81, 822-825.

Romaine, C.P. and Schlagnhaufer, B. (1993). 'DsRNA Quick-Prep: an abbreviated method for clinical diagnosis of La France disease. Cultivated Mushroom Research Newsletter 1:7-10.

Romaine, C.P. and Schlagnhaufer, B. (1995). PCR analysis of the viral complex associated with La france disease of Agaricus bisporus. Appl. Environ. Microbiol. 61, 2322-2325.

Romaine, C.P. (2000). Family Barnavirida: In Virus Taxonomy-Classification and nomenclature of viruses (van Regenmortel, M. H. V., Fauquet, C. M., Bishop, D. H. L., Carstens, E. B., Estes, M. K., Maniloff, J., Mayo, M. A., McGeoch, D. J., Pringle, C. R. and Wickner, R. B. eds). Academic Press, NY.

Romaine, C.P. (2002). Gene transfer technology for mushrooms: the power and potential for significant crop improvement. Mushroom News 50, 4-14.

Romaine, C.P. and Goodin, M. M. (2002). Unravelling the viral complex associated with La France disease of the cultivated mushroom Agaricus bisporus. In DsRNA genetic elements: Concepts and Applications in Agriculture, Forestry and Medicine. CRC press. 237257.

Romaine, C.P. (2003). Bacterial transformations of fungi. In McGraw-Hill Yearbook of Science and Technology 2003. McGraw-Hill Companies, Inc. New York. 29-31.

Romaine, C.P. Chen, X. and Schlagnhaufer, B. (2004). Fruting body gene transfer method for Agaricus bisporus potentiates crop improvement and 'pharmining'. In Mushroom Science XVI Science and Cultivation of Edible and Medicinal Fungi. Romaine, C.P. Keil, C. B., Rinker, D. L. and Royse, D. J. (eds), Penn State, USA. 117-123.

Sonnenberg, A.S.M., Van Kempen, I.P.J. and van Griensven, L.J.L.D. (1995). Detection of Agaricus bisporus viral dsRNAs in pure cultures, spawn and spawn-run compost by RT-PCR. In Science and Cultivation of Edible fungi (Elliot, T. ed). Balkema, Rotterdam, The Netherlands. 587-594.

Sonnenberg, A.S.M. and Lavrijssen, B. (2004). Browning of mushrooms and the presence of viral double-stranded 
RNA in Dutch mushrooms. Mushroom Science XVI. Science and Cultivation of Edible and Medicinal fungi. Romaine, C.P. Keil, Rinker and Royse (eds). Penn State, USA 541-546.

Sambrook, J. and Russell, D.W. (2001). Molecular Cloning. A laboratory manual. Cold Spring Harbor Laboratory Press, NY.

Takata, K., Ishikawa, G., Hirose, F. and Sakaguchia, K. (2002). Drosophila damage-specific DNA-binding protein 1 (D-DDB1) is controlled by the DRE/DREF system Nucleic Acids Res. 2002 September 1; 30, 3795-3808.

Tavantzis, S.M., Romaine, C.P. and Smith, S.H. (1980). Purification and partial characterisation of a bacilliform virus from Agaricus bisporus: a single stranded RNA mycovirus. Virology 105, 94-102.

Tavantzis, S.M., Romaine, C.P. and Smith, S.H. (1983). Mechanism of genome expression in a single-stranded RNA virus from the cultivated mushroom Agaricus bisporus. Phytopathol. Z. 106, 45-50.

Thompson, A.H., Bjourson, A.J., Shaw, C. and McClean, S. (2006). Bradykinin-related peptides from Phyllomedusa hypochondrialis azurea: Mass spectrometric structural characterisation and cloning of precursor cDNAs. Rapid Communications in Mass Spectrometry (in press).

Tsukamoto, T., Murate, H. and Shirat, A. (2002). Identification of Non-pseudomonad bacteria from fruiting bodies of wild agaricales fungi that detoxify tolaasin produced by Pseudomonas tolaasii. Biosci. Biotechnol. Biochem. 66, 2201-2208.

van Regenmortel, M.H.V., Fauquet, C.M., Bishop, D.H.L., Carstens, E.B., Estes, M.K., Maniloff, J., Mayo, M.A., McGeoch, D.J., Pringle, C.R. and Wickner, R.B. (2000).
Virus Taxonomy - classification and nomenclature of viruses. Academic Press, NY.

Vreede, F.T., Cloete, M., Napier, G.B., van Dijk, A.A. and Viljoen, G.J. (1998). Sequence- independent amplification and cloning of large dsRNA virus genome segments by poly(dA)-oligonucleotide ligation. J. Virol. Methods 72, 243-247.

Volossiouk, T., Robb, E.J. and Nazar, R.N. (1995). Direct DNA extraction for PCR-mediated assays of soil organisms. Appl. Environ. Microbiol. 61, 3972-3976.

Wach, M.P., Sriskantha, A. and Romaine, C.P. (1987). Double-stranded RNA associated with La France disease of the commercial mushroom. Phytopathology 77, 1321-1325.

Watabe, M., Rao, J.R., Murphy, A.R. and Moore, J.E. (2003). Inhibition of Listeria ivanoii by Paenibacillus lentimorbus isolated from phase II mushroom compost. World J. Microbiol. Biotechnol. 19, 875-877.

Watabe, M., Rao, J.R. Xu, J., Millar, B.C., Ward, R.F., and Moore, J.E. (2004). Identification of novel eubacteria from spent mushroom compost (smc) by rDNA sequence typing: ecological considerations of disposal on agricultural land. Int. J. Waste Management, Sci. Tech., 24, 81-86.

Wilson, D.S. and Yoshimura, J. (1994). On the coexistence of specialists and generalists. Am. Nat. 144, 692-707.

Wong, W.C. and Preece, T.F. (1979). Identification of Pseudomonas tolaasii: the white line test in agar and mushroom block rapid pitting tests. J Appl. Bacteriol. 47, 401-407.

Zhou, J., McClean, S., Thompson, A., Zhang, Y., Shaw, C., Rao, P. and Bjourson, A.J. (2006). Purification and characterization of novel antimicrobial peptides from the skin secretion of Hylarana guentheri. Peptides 27, 3077-3084. 


\section{Further Reading}

Caister Academic Press is a leading academic publisher of advanced texts in microbiology, molecular biology and medical research. Full details of all our publications at caister.com

- MALDI-TOF Mass Spectrometry in Microbiology Edited by: M Kostrzewa, S Schubert (2016) www.caister.com/malditof

- Aspergillus and Penicillium in the Post-genomic Era Edited by: RP Vries, IB Gelber, MR Andersen (2016) www.caister.com/aspergillus2

- The Bacteriocins: Current Knowledge and Future Prospects Edited by: RL Dorit, SM Roy, MA Riley (2016)

www.caister.com/bacteriocins

- Omics in Plant Disease Resistance Edited by: V Bhadauria (2016) www.caister.com/opd

- Acidophiles: Life in Extremely Acidic Environments Edited by: R Quatrini, DB Johnson (2016) www.caister.com/acidophiles

- Climate Change and Microbial Ecology: Current Research and Future Trend

Edited by: J Marxsen (2016)

www.caister.com/climate

- Biofilms in Bioremediation: Current Research and Emerging Technologies

Edited by: G Lear (2016)

www.caister.com/biorem

- Microalgae: Current Research and Applications Edited by: MN Tsaloglou (2016) www.caister.com/microalgae

- Gas Plasma Sterilization in Microbiology: Theory, Applications, Pitfalls and New Perspectives Edited by: H Shintani, A Sakudo (2016) www.caister.com/gasplasma

- Virus Evolution: Current Research and Future Directions Edited by: SC Weaver, M Denison, M Roossinck, et al. (2016) www.caister.com/virusevol

- Arboviruses: Molecular Biology, Evolution and Control Edited by: N Vasilakis, DJ Gubler (2016) www.caister.com/arbo

- Shigella: Molecular and Cellular Biology Edited by: WD Picking, WL Picking (2016) www.caister.com/shigella

-Aquatic Biofilms: Ecology, Water Quality and Wastewater Treatment

Edited by: AM Romaní, H Guasch, MD Balaguer (2016)

www.caister.com/aquaticbiofilms

- Alphaviruses: Current Biology

Edited by: S Mahalingam, L Herrero, B Herring (2016)

www.caister.com/alpha

- Thermophilic Microorganisms

Edited by: F Li (2015)

www.caister.com/thermophile
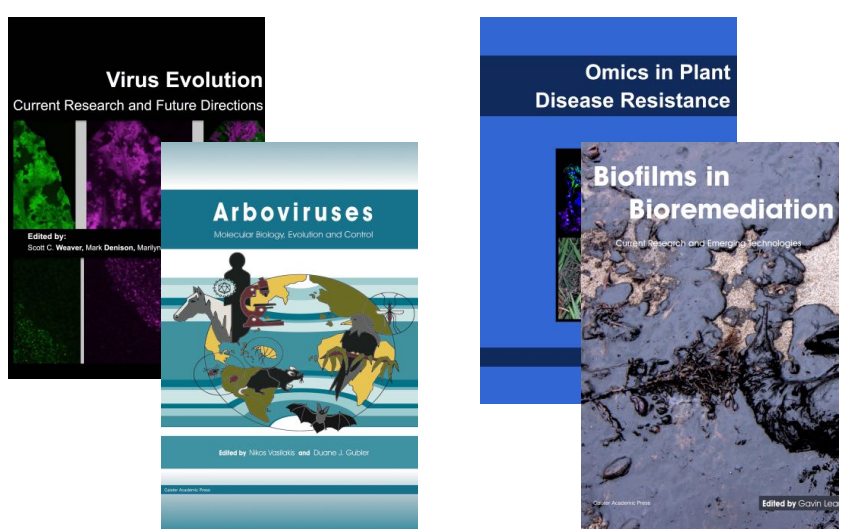
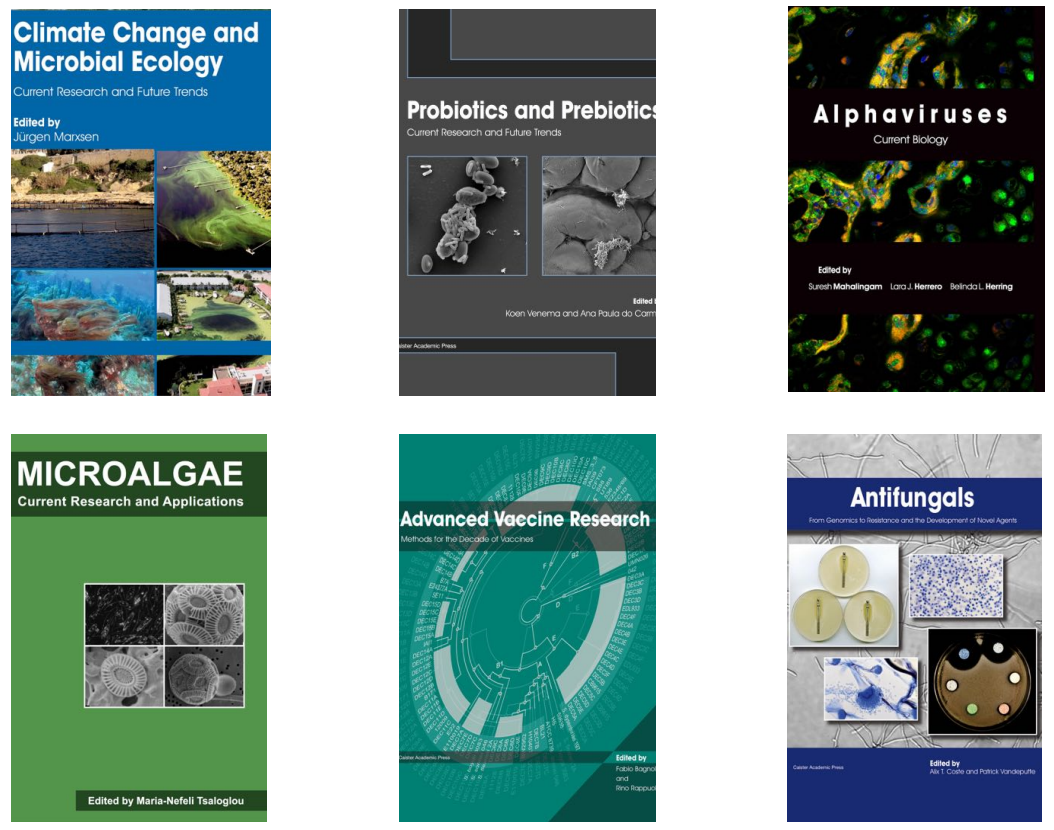

- Flow Cytometry in Microbiology: Technology and Applications Edited by: MG Wilkinson (2015) www.caister.com/flow

- Probiotics and Prebiotics: Current Research and Future Trends Edited by: K Venema, AP Carmo (2015) www.caister.com/probiotics

- Epigenetics: Current Research and Emerging Trends Edited by: BP Chadwick (2015) www.caister.com/epigenetics2015

- Corynebacterium glutamicum: From Systems Biology to Biotechnological Applications

Edited by: A Burkovski (2015)

www.caister.com/cory2

- Advanced Vaccine Research Methods for the Decade of Vaccines

Edited by: F Bagnoli, R Rappuoli (2015)

www.caister.com/vaccines

- Antifungals: From Genomics to Resistance and the Development of Novel Agents

Edited by: AT Coste, P Vandeputte (2015)

www.caister.com/antifungals

- Bacteria-Plant Interactions: Advanced Research and Future Trends Edited by: J Murillo, BA Vinatzer, RW Jackson, et al. (2015) www.caister.com/bacteria-plant

\section{- Aeromonas}

Edited by: J Graf (2015)

www.caister.com/aeromonas

- Antibiotics: Current Innovations and Future Trends

Edited by: S Sánchez, AL Demain (2015)

www.caister.com/antibiotics

- Leishmania: Current Biology and Contro Edited by: S Adak, R Datta (2015) www.caister.com/leish2

- Acanthamoeba: Biology and Pathogenesis (2nd edition) Author: NA Khan (2015)

www.caister.com/acanthamoeba2

- Microarrays: Current Technology, Innovations and Applications Edited by: Z He (2014)

www.caister.com/microarrays2

- Metagenomics of the Microbial Nitrogen Cycle: Theory, Methods and Applications

Edited by: D Marco (2014)

www.caister.com/n2 